\title{
Providing Public Assistance: Cognitive and Motivational Processes Underlying Liberal and Conservative Policy Preferences
}

\author{
Linda J. Skitka and Philip E. Tetlock
}

\begin{abstract}
Previous research in a wide variety of policy domains (e.g., azidothymidine for AIDS patients, lowincome housing) has indicated that under no scarcity, liberals tend to help all claimants for assistance, whereas conservatives withhold assistance from people who are personally responsible for their predicament (Skitka \& Tetlock, 1992). Three studies explore 6 explanations for this robust finding: deterrence, self-interest, punitiveness, mindlessness, value orientation, and avoidance of trade-off reasoning. The findings shed light on both the cognitive strategies and motivational priorities of liberals and conservatives. It was discovered that liberals are not mindlessly egalitarian, but try to avoid socially awkward value trade-offs that require placing monetary values on lives. By contrast, conservatives are motivated to punish violators of social norms (e.g., deviations from traditional norms of sexuality or responsible behavior) and to deter free riders.
\end{abstract}

The United States is still one of the most prosperous countries in the world. However, millions of people are destitute and rely on the generosity of the community for their survival. What obligations does the community have to these people? What responsibilities do these people have to the community? Answers to these basic questions depend largely on one's political point of view. In the $1960 \mathrm{~s}$, the Johnson administration declared war on poverty and the welfare state proliferated. In the 1980 s and early 1990s, many political leaders concluded that the welfare state was a failure, and stressed the virtues of self-reliance and free markets. The political pendulum appears to swing between individualism and egalitarianism (albeit not with the clocklike regularity some suppose; $\mathrm{cf}$. Schlesinger, 1986).

Survey research reveals that attitudes toward social welfare are consistently correlated with ideologically patterned attributions for poverty (Sniderman, Hagen, Tetlock, \& Brady, 1986). Conservatives blame poverty on self-indulgence and lack of moral standards and intelligence. Liberals see the poor as victims of unjust social practices and structures. These ideological differences in attributions for poverty predict a willingness to expand social programs. Liberals generally favor increased spending on social programs, whereas conservatives oppose such spending (Feather, 1985; Kluegel, 1990; Kluegel \& Smith, 1986; Sniderman \& Tetlock, 1986; Williams, 1984).

Linda J. Skitka, Department of Psychology, Southern Illinois University at Edwardsville; Philip E. Tetlock, Department of Psychology, University of California, Berkeley.

Neil Christiansen, Laura Stephens, Richard Eaves, Bruce Aebel, and Elaina Edwards deserve thanks for their assistance with data collection at Southern Illinois University, as does Charles McGuire, Jr., for assistance with data collection at the University of California, Berkeley. This research was facilitated by a fourth quarter research fellowship and a funded university research project grant from Southern Illinois University to Linda J. Skitka.

Correspondence concerning this article should be addressed to Linda J. Skitka, Department of Psychology, Southern Illinois University, Edwardsville, Illinois, 62026-1121. Electronic mail may be sent to sm01@siuemus (Bitnet).
In an experimental study, Skitka and Tetlock (1992) found that willingness to help those personally responsible for needing assistance was critically dependent on resource availability. They examined liberal and conservative allocations under no, low, and high scarcity in three resource domains: azidothymidine (AZT) for AIDS patients, organs for would-be transplant recipients, and low-income housing for the poor. They derived claimant descriptions for each policy domain from a three-factor design of locus of responsibility (internal-controllable, internal-uncontrollable, external-controllable, external-uncontrollable), need (high, low), and efficiency (high, low) that yielded a total of 16 claimants per resource domain. Under high scarcity, subjects could select only 3 of 16 claimants to receive assistance, and under low scarcity, they could select 13 of 16 claimants to receive assistance (none of the subjects allocated less assistance than the maximum allowed). Under no scarcity, subjects could select as many or as few claimants as they thought fair.

Under scarcity, both liberals and conservatives denied assistance to people they deemed personally responsible for their plight. Claimants who bore no personal responsibility for their predicament received assistance if the need was urgent, and there was a high likelihood that aid would be effective. Under no scarcity, conservatives continued to withhold assistance from internal-controllable claimants, whereas liberals helped everyone.

Skitka, McMurray, and Burroughs (1991) noted similar results in a study of willingness to help Iraq after the Persian Gulf War. Conservatives held the Iraqi people and leaders more responsible for the war than liberals and were less supportive of providing postwar assistance. Of those subjects who justified their aid allocations by describing Iraq's responsibility for the war, $63 \%$ provided no assistance to Iraq, as compared to $23 \%$ of those who cited any other justification. Priming subjects with a pessimistic economic forecast (i.e., resource scarcity) heightened these effects. These results contributed to the growing research that indicates people are least likely to help those whose need they attribute to internal-controllable causes (e.g., Levin 
\& Chapman, 1990; Weiner, 1986). The results also underscored the idea that the ideological orientation of the perceiver and resource scarcity are important moderators of this general finding.

This article reports on three studies that probed the psychological sources of political disputes over allocation policies. The first study explored two sets of issues: (a) Do liberals and conservatives differ not only in the types of people they are willing to help, but also in their willingness to make personal sacrifices when claimant demands exceed the capacity of the collective resource pool? and (b) What combination of cognitive and motivational explanations best accounts for ideological differences in willingness to expand spending on an AIDS treatment program?

The second study explored the psychological roots of ideological disagreements. Specifically, when resources are abundant is liberal egalitarianism the product of careful reasoning about the pros and cons of helping in each specific case, or does liberal egalitarianism reflect a general desire to avoid cognitively complex and emotionally painful trade-offs? The third study shifted attention from liberals' willingness to help to conservatives' unwillingness to help. Do conservatives withhold assistance from personally responsible claimants to punish them for violating traditional values (e.g., the work ethic) or to set an example to deter would-be free riders?

\section{Political Ideology and Personality}

Political ideologies prescribe both the causes of poverty and societal solutions. Conservatives argue that an overblown welfare state has undermined the vitality of the private economy and sapped self-reliance among the poor (e.g., Gilder, 1981; Murray, 1984). Liberals argue that the war on poverty has accomplished a great deal, and would have accomplished much more if spending had not been cut by Republican administrations (Levitan \& Johnson, 1984; Schwartz, 1983). Consistent with these positions, conservatives believe that the solution for poverty is to reduce welfare dependency by cutting aid and encouraging self-reliance in an expanding free-market economy. Liberals advocate expanding welfare benefits and job training programs for the poor who, in their view, are often ill-equipped to compete for opportunities in the market economy.

Researchers have documented numerous links between personality measures and both ideology and allocation preferences (see Major \& Deaux, 1982 for a review). For example, belief in the Protestant ethic-that hard work will ultimately be rewarded-is associated with skepticism toward the value of equality, a preference for allocating outcomes according to merit, a tendency to attribute behavior internally to people rather than externally to the system, and a conservative political orientation (Garrett, 1973; Greenberg, 1978; MacDonald, 1971).

Theorists have organized these overlapping personality and attitudinal variables into ideological/affective/cognitive stylistic resonances (Alker \& Poppen, 1973; Carroll, Perkowitz, Lurigio, \& Weaver, 1987). One resonance, cognitive conser vatism, combines support for traditional power structures and opposition to egalitarianism with personality measures of dogmatism, authoritarianism, and intolerance of ambiguity (a resonance re- markably reminiscent of the classic work on authoritarianism; Adorno, Frenkel-Brunswik, Levinson, \& Sanford, 1950). The second resonance, liberal humanism, combines a liberal political orientation, egalitarian-humanism, and the principled stage of Kolhbergian moral development (e.g., Carroll et al., 1987; Eysenck, 1971; Skitka \& Tetlock, 1992). ${ }^{1}$ The close conceptual and empirical links between personality and political ideology have also been noted by other researchers (e.g., Hogan \& Dickstein, 1972; Tetlock, 1984). Focusing on operational definitions, one could argue, on both conceptual and psychometric grounds, that an item such as "Many poor people simply do not want to work hard" could just as easily be part of an ideology as an authoritarianism scale. Our position is that we will gain a more robust understanding of individual differences in political ideology and personality when we concentrate empirical effort on assessing well-replicated, broad-band resonances, rather than attempting to isolate the intercorrelated components of each resonance (see Study 2 Method section). For simplicity of presentation, however, we will refer to conservatives and liberals rather than to cognitive conservatives or liberal humanists, and refer to their resonances as ideology.

\section{Flattering and Unflattering Explanations of Ideological Differences in Allocations Under no Scarcity}

Subjects in Skitka and Tetlock's (1992) study could not control scarcity of public resources. This situation is not unusual. For example, physicians cannot control organ donation rates or the cost of drugs. But it is sometimes possible in the political world to influence the availability of public resources; for example, legislators can opt to decrease scarcity by increasing taxes, or vice versa. ${ }^{2}$

We sought to extend our previous research by giving subjects additional options for coping with scarcity beyond deciding who should receive assistance. In contrast to Skitka and Tetlock's (1992) study, subjects in our study began by making allocations to social programs (dividing a budget to different health and social programs) instead of to individuals. Afterward, subjects learned that one program was not allocated enough money (always AZT for AIDS patients). Subjects then had an opportunity to vote to expand the resource pool to help all claimants. Subjects knew that if the vote did not pass, they would have to decide which individual claimants should go without assistance. In the political world, decisions to expand the resource pool

\footnotetext{
' These results reflect the widespread reliance on college student samples drawn from one country (the United States) and from a narrow band of time (late 20th century). Other possible resonances include libertarianism (strong needs for autonomy fused with support for liberalism on social issues and conservatism on economic issues) and coercive egalitarianism (envy and resentment of the wealthy fused with support for authoritarian means of redistributing wealth).

${ }^{2}$ Other views of the trade-off between taxes and resource availability are possible. For example, some conservatives believe that increasing taxes increases scarcity by reducing economic growth. The issue becomes at what point do we overtax (reach the point of diminishing returns)? Liberals and conservatives are likely to have very different perceptions of when losses in economic growth outweigh gains in caring for the disadvantaged.
} 
usually involve costs (e.g., higher taxes or deficit spending). To capture this contingency, half of the subjects expected to sacrifice a large portion of their pay if they expanded the budget; the other half expected no personal sacrifice. The primary dependent measures were how much aid people allocated to specific spending programs, whether they voted to expand the budget to help all claimants, and the explanations they offered for these choices.

We chose AIDS patients as the primary claimant population for a variety of reasons. Resource allocations to AIDS patients have recently become the focus of intense policy debates. In particular, the high costs of caring for AIDS patients (federal spending was expected to reach $\$ 4.3$ billion in 1992 ; Winkenwerder, Kessler, \& Stolec, 1989) has raised concern that needed funding for other diseases has been diverted to AIDS related research and treatment (Krieger, 1988). Others claim, however, that AIDS has not been overfunded based on econometric analyses of mortality data (e.g., Hatziandreu, Graham, \& Soto, 1988; Winkenwerder et al., 1989). Still others argue that hostile reactions to populations at special risk for AIDS (e.g., homosexual males, intravenous drug users, and minorities) severely limit public support for AIDS treatment and research (Chapman, Levin, \& Kuhn, 1991; Rogers, 1989). Large scale surveys have found support for this idea: Conservatives are more likely to have antigay attitudes, and these antihomosexual attitudes predict opposition to government spending on AIDS, support for issuing identification cards or even tattooing human immunodeficiency virus (HIV)-infected people, and a host of other policy stands (Ostrow \& Traugott, 1988; Price \& Hsu, 1992; Sniderman, Wolfinger, Mutz, \& Wiley, 1987).

Other research indicates that reactions to AIDS patients are driven by attributions of personal responsibility to homosexuals and intravenous drug users for their illness (e.g., Kite, Whitley, Jr., Michael, \& Simon, 1991; Levin \& Chapman, 1990; Weiner, 1992; Weiner, Perry \& Magnusson, 1988). Controlling for how homosexual AIDS patients contracted the disease (e.g., through risky sexual practices vs. through a blood transfusion) usually eliminates any effects for homophobia. Although these investigators have clearly linked attributions of responsibility to derogation of AIDS patients, they have yet to demonstrate linkages of attributions of personal responsibility to withholding resources at either the individual or programmatic level.

We anticipated that liberals would vote to expand the resource pool to help all claimants, whereas conservatives would not. We also tested several psychological hypotheses to explain this predicted difference, including (a) punitiveness, (b) homophobia, (c) value expression, (d) trade-off avoidance, and (e) self-interest.

\section{Punitiveness Hypothesis}

Conservatives are more motivated than liberals to punish violators of traditional values and norms, and may even relish the opportunity to do so. In support of this hypothesis, Skitka and Tetlock (1992) found that conservatives had stronger negative emotional reactions to targets, made stronger attributions of personal responsibility, and withheld more aid from personally responsible claimants under both scarcity and no scarcity. The affective data (e.g., anger and disgust ratings) were consistent with the idea that conservatives wanted to punish personally responsible claimants for breaking an implicit social contract. If people want to enjoy the benefits of society, then they should behave responsibly; if not, they should accept the natural consequences of their actions. Other research has also supported connections between attributions of responsibility, negative affect, and retribution or punishment (e.g., Betancourt \& Blair, 1992).

In contrast to conservatives, liberals were more sympathetic to personally responsible claimants. Under no scarcity liberals tended to aid all claimants and under scarcity, liberals denied aid to personally responsible claimants but they did so reluctantly and regretfully, with little evidence of anger or punitiveness.

The punitiveness hypothesis is consistent with Tomkins's (1965) ideo-affective theory which posits that political ideologies contain emotionally charged scripts that govern our responses to events. Conservatives, in this view, have much lower thresholds for anger and annoyance, whereas liberals have lower thresholds for compassion and empathy.

The punitiveness hypothesis is also consistent with Carroll et al.'s (1987) work on linkages among ideology, attributions, and sentencing goals. Conservatives are more likely to attribute crime to individual greed and self-interest and to assign harsher sentences. By contrast, most liberals believe that the causes of crime reside in external, sociocultural, and macroeconomic forces, and impose more lenient sentences. Other recent research (Peterson, Doty, \& Winter, 1993) has found strong relationships between right-wing authoritarianism (as measured by Byrne's Balanced F scale [see Cherry \& Byrne, 1977, pp. 118 119]) and Altemeyer's (1981, 1988) Right-Wing Authoritarianism scale and the likelihood of endorsing harsh, punitive sentiments toward AIDS and illegal drugs.

\section{Homophobia Hypothesis}

Antihomosexual attitudes are correlated with both opposition to government spending on AIDS (Herek, 1989; Herek \& Glunt, 1988; Ostrow \& Traugott, 1988) and political conservatism (Altemeyer, 1988; Price \& Hsu, 1992; Skitka \& Tetlock, 1993). The homophobia hypothesis asserts, however, that this is more than a simple correlational connection. It asserts that conservatives will discriminate against homosexual claimants for government aid because they dislike, fear, and even hate homosexuals, an effect that is not reducible to either the tendency of conservatives to oppose government spending in general or the tendency of conservatives to withhold aid from people judged personally responsible for their plight (e.g., the promiscuous).

In support of the homophobia hypothesis, several writers claim that conservatives generally react more defensively toward homosexuals than do liberals; they attribute unacceptable motives to homosexuals and express open hostility toward them (Altemeyer, 1988; Price \& Hsu, 1992). However, other research indicates that conservatives deny assistance not only to AIDS patients, but also to people personally responsible for needing housing and organ transplants, and to those perceived as responsible for starting a war (Skitka et al., 1991; Skitka \& Tetlock, 1992). In a similar vein, research has found that attribu- 
tions of responsibility are better predictors of reactions to homosexual AIDS patients than homophobia (e.g., Kite et al., 1991; Mallery, 1990; Weiner, 1992). But other researchers have reported homophobic reactions to AIDS patients even when controlling for source of infection (Triplet \& Sugarman, 1987).

\section{Trade-Off Avoidance Hypothesis}

The value pluralism model (Tetlock, 1986) maintains that liberals often hold conflicting values (e.g., encourage responsible behavior vs. help the needy, keep taxes down vs. help the needy, save lives vs. bankrupting the economy). To cope, liberals try to redefine situations that require assigning specific weights to these values and arriving at specific resolutions. For example, one way of avoiding placing an explicit monetary value on human lives or suffering is to decide to help everyone. Other strategies of trade-off avoidance include noncompensatory choice heuristics and both buck passing and procrastination (Abelson \& Levi, 1985; Janis \& Mann, 1977; Tetlock, 1986; Tetlock \& Boettger, 1992).

\section{Value Expression: Egalitarianism Versus Self-Reliance}

Ideological differences in allocating aid may simply stem from the desire to express one's fundamental values. Liberals might distribute aid equally to all who require it (regardless of why they need it) because they feel ideologically committed to social equality, whereas conservatives withhold aid to uphold their valued commitment to self-reliance and efficiency (see Rasinski, 1987).

\section{Self-Interest Hypothesis}

Conservatives are less willing than liberals to pay for social programs, and refuse to expand the resource pool because they want to avoid higher taxes and incurring other personal costs. This unwillingness may reflect the greater value that conservatives place on preserving personal wealth or the greater likelihood that liberals place on their needing government help later (fear of falling).

\section{Reprise}

To summarize, we expect (a) conservatives will be less likely than liberals to cope with scarcity by augmenting the total budget to help all claimants, and (b) these differences may be traceable to any (or some combination) of these political psychological processes.

\section{Study 1 \\ Method}

\section{Subjects}

Subjects who participated in this study received partial fulfillment of requirements for a course in introductory psychology. Two different locations were used to increase the range of political ideology: Southern Illinois University $(N=84)$ and the University of California, Berkeley $(N=82)$.

\section{Procedure}

Subjects participated in small groups of 3 to 5 . Subjects first met in a central laboratory area and were given scripted instructions. Subjects were informed that they were participating in a study of how people make fair allocation decisions; that their task was to fill out several questionnaires; their confidentiality would be protected; and besides course credit, they would be paid up to $\$ 3$ for their participation.

Subjects were then led into separate cubicles. The doors were left open for the experimenter to announce instructions and collect questionnaires. Subjects received verbal and written instructions to imagine they were in the role of a director of a health and human services agency in a large democratic society. As part of their job, they had to distribute a budget across programs run by the agency. The total budget was $\$ 100$ million. They were told to allocate these funds based on their perception of the importance of each program in any value ranging from $\$ 0$ to $\$ 100$ million (not to exceed their total budget) and to assume equal numbers of claimants per program. The following information (based loosely on existing programs in the United States) was presented to the subjects:

Women. Infants and Children Program (WIC). WIC is a special supplemental food program for poor women and their infants or young children. The goal of this program is to supply nutritional foods for poor, pregnant, or breast-feeding women; infants; and children under 5 years of age.

Organ Transplantation Act. This act guarantees access to (i.e., mandates that taxpayers will pay for) organ transplants and kidney dialysis for people who do not have medical insurance to cover these kinds of procedures.

AZT subsidies. Through this program, AZT (an expensive drug that prolongs the life of AIDS patients but does not cure the disease) is provided to people who have Acquired Immunodeficiency Syndrome and who do not have medical insurance to cover the cost of this drug.

Family Planning. This program provides services in planning the number and timing of children. Family planning centers provide advice and dispense birth control, abortion counseling, and prenatal care to pregnant women.

Healthy Kids Program. This program provides check-ups, prevention (i.e., immunizations), and treatment for children who participate in Medicaid or other medical assistance programs for the poor.

Medicaid and medical assistance programs. These programs pay for most of the medical costs for poor people. Eligibility is based on income, disability, and number of dependent children.

Independent Living Program. This program provides funds to operate centers that focus on rehabilitation for the disabled and fund the provision of special devices (e.g., telephones for the deaf; Braille translation of texts).

Mental health services. These programs provide services ranging from long term care for the severely mentally retarded to subsidized counseling programs for the poor.

After allocating their budget, subjects were required to check that their total spending did not exceed $\$ 100$ million. The experimenter then collected the allocation questionnaires and distributed another questionnaire designed to tap perceptions of program efficiency and genuine neediness (or lack of personal responsibility) of program claimants. Program descriptions were provided again, and parallel versions of the following questions for each program were presented. Subjects responded on 1 to 5 scales, where 1 represented not at all true and 5 represented very true. Questions regarding the WIC program, for example, were as follows:

I think this program . . . 
is effective in supplying the special nutritional needs of poor and pregnant or breast-feeding women; infants and young children.

serves a population that is truly in need.

helps people to become more productive members of society.

serves people who, because of circumstances, are currently unable to provide sufficiently for themselves.

serves people who just want a "free ride."

serves people who need help because they do not try hard to help themselves.

serves people who would rather not be dependent on governmental support.

is cost effective; the benefits society as a whole derives from this program are in balance with or exceed how much it costs to provide this assistance.

While subjects completed this questionnaire, the experimenter feigned tabulating the budget allocation questionnaires. After all the subjects had finished their questionnaires, the experimenter distributed a Feedback Sheet which indicated "whether each of your programs were adequately funded. If your feedback sheet indicates that all your programs were adequately funded, you need do nothing with it. If any of your programs were not adequately funded however, you need to make a determination regarding how you want to proceed." Subjects were then instructed to study the two options confronting them very carefully before they made any decisions.

Feedback sheets always indicated that every program was adequately funded except for the AZT drug program (red ink was used for contrast). To emphasize that feedback was contingent on their personal allocations, there was (besides the handwritten check mark) a brief handwritten comment in a space marked "implications": "If you do not increase the amount of funding available, you will have to decide who will receive, versus who will be denied, aid in this program."

Instructions informed subjects that if their allocations funded all programs adequately, they could stop there. If however, any program was inadequately funded, they needed to check one of the following options:

Check here if you do not want to increase the amount of funding available for all the programs to be adequately funded. Your next step will be to consider different people who have applied for governmental assistance under this program, and decide which applicants should receive assistance, and which applicants should be denied assistance (choosing this option does not change your pay).

- Check here if you wish to increase the size of your budget to adequately fund all programs, and thereby continue to provide services to everyone who requires them. In other words, you can vote "to increase taxes" to cover the needs of these programs. To simulate the democratic process, the size of your total budget (and the other subjects' budgets) can only be increased if most of you vote to do so. Also, to simulate "increasing taxes," it will cost you $\$ 2$ of your pay if you vote to increase the size of your budget, and the vote passes (if you choose this option, and a vote does not pass, you will be able to keep your full pay). Checking here indicates that you vote to increase the budget.

Half of these feedback sheets included mentions of cost (italicized for clarity here); the other half omitted these references.

The experimenter collected these questionnaires and announced, "I need to get together the right sets of questionnaires based on how your group voted. While I am doing this, please fill out this next questionnaire regarding why you voted the way you did." This questionnaire assessed agreement with the various reasons subjects chose to vote the way they did (e.g., to avoid deciding who should receive assistance; ob- ligation to stick by their earlier allocations; the belief that everyone should receive assistance, despite the personal cost; or separately, how much it cost society).

\section{Measures}

Liberalism-conservatism. To measure the cognitive conservatism and liberal-humanism factors identified in earlier research (high scores on dogmatism, authoritarianism, and identification with the political right; Skitka \& Tetlock, 1992) we adopted Altemeyer's $(1981,1988) 30$ item balanced Right-Wing Authoritarianism (RWA) scale. The RWA scale is an updated measure with sound psychometric properties (see review by Winter, 1990) that we judged to be superior to the scales we used in earlier studies of ideo-affective resonances. The scale ranges from liberal-democrat to authoritarian (see Altemeyer, 1988, p. 263). ${ }^{3}$ Altemeyer (1981) reported Cronbach's alpha of .88 for a sample of 965 University of Manitoba students. We observed an alpha of .86 with the present sample, indicating adequate internal consistency in measuring the construct.

Attitudes toward homosexuality. We used Herek's (1987) Attitude Functions Inventory (AFI) to assess four possible functions of attitudes toward gays and lesbians: Experiential-Schematic (opinions are the result of personal experiences), Social-Expressive (opinions are influenced by respected role models), Defensive (opinions are the result of avoidance or feelings of revulsion toward homosexuality), and Value-Expressive (opinions are based on concern for protecting civil liberties or moral beliefs).

General impressions of AIDS victim locus of responsibility and AZT program efficiency. We used principal components analysis (varimax rotation) to simplify the dependent measures of personal responsibility and efficiency. Two components emerged that were internally consistent and well-defined. The first component accounted for $45.6 \%$ of the variance, and represented belief in the external causes of claimants' needs and in the effectiveness of helping people to become more productive members of society (EE: External-Effective). The second component accounted for $20.5 \%$ of the variance, and represented belief in internal causes and in the tendency of program recipients to be free riders (PR: Personal Responsibility). A separate principal components analysis with just the AZT program items replicated the component structure across programs, with only minor variations in loading weights, but no differences in rank ordering of items (see Table 1). Components derived using the regression method with the AZT items were used in subsequent analysis.

Beyond the data-reduction function, these results are interesting in their own right. The belief in external causality is tied to the conviction that these kinds of programs are effective in solving the social problems. Attributions of personal responsibility (internal-controllable causes) are independent of beliefs regarding efficacy.

Decision avoidance and egalitarianism. After voting, subjects could endorse or reject several reasons for their votes. A principal-components analysis of these 10 items yielded two well-defined and internally consistent components that converged in four iterations of a varimax rotation that we labeled Decision Avoidance and Egalitarianism (see Table 2). Component scores used in further analysis were derived by the regression method.

\footnotetext{
${ }^{3}$ In Studies 2 and 3 we also included Katz and Hass's (1988) Humanitarianism scale, Rasinski's (1987) personal values (egalitarianism and proportionality) scales, and self-reported political ideology in addition to RWA. Since Study 1, our research has indicated that we get consistently clearer and stronger effects using multiple measures of personality and political ideology that include broad measures of political values, than when we use RWA alone. See the method of Study 2 for additional elaboration.
} 


\section{Results}

Our primary hypothesis involved ideological differences in willingness to expand the budget to help all claimants of AZT. Specifically, we expected liberals to be more likely to expand the budget to help all claimants than conservatives. This hypothesis was supported. ${ }^{4}$ Before turning to these results and analyses exploring covariates of the ideology-vote effect, descriptive analysis of the budget allocations across programs, and willingness to support the AZT program in particular, are described.

\section{Budget Allocations}

The AZT for AIDS patients program received the lowest funding of any program (see Table 3 ). A within-subjects analysis of variance (ANOVA) indicated that programs did not receive equal budgets, $F(7,1,141)=17.99, p<.001$. Tukey tests revealed that Medicare and WIC programs received the largest budget allocation and AZT the smallest budget allocation.

\section{AZT Budget Allocations}

Scores on RWA, EE, PR, and the four subscales of Herek's (1987) AFI scale explained $29.97 \%$ of the variance in spending on the AZT program in a standard regression equation, $F(6$, $159)=11.34, p<.05$. Only the EE component contributed

Table 1

Principal Components Analysis of General Impressions of AIDS Patients Seeking Subsidized Azidothymidine (AZT) Treatment

\begin{tabular}{lcc}
\hline \multicolumn{1}{c}{ Variable } & $\begin{array}{c}\text { Component 1: } \\
\text { External/ } \\
\text { Efficiency }\end{array}$ & $\begin{array}{c}\text { Component 2: } \\
\text { Personal } \\
\text { Responsibility }\end{array}$ \\
\hline $\begin{array}{l}\text { Eigenvalue } \\
\text { Percentage of variance }\end{array}$ & 3.01 & 1.19 \\
I think this program ... \\
serves a population that is truly \\
in need. \\
$\begin{array}{l}\text { is effective in extending the lives } \\
\text { of AIDS patients. }\end{array}$ \\
$\begin{array}{l}\text { is cost effective; the benefits } \\
\text { society as a whole derives } \\
\text { from this program are in } \\
\text { balance with or exceed how } \\
\text { much it costs to provide this } \\
\text { kind of assistance. }\end{array}$ \\
helps people become productive \\
members of society. \\
serves people who, because of \\
circumstances, are currently \\
unable to provide sufficiently \\
for themselves. \\
serves people who would rather \\
not be dependent on \\
governmental support. \\
serves people who need help \\
because they do not try hard \\
to help themselves. \\
serves people who just want a \\
free ride.
\end{tabular}

Table 2

Principal Components Analysis of Reasons for Vote to Expand the Resource Pool to Help all Claimants

of Azidothymidine $(A Z T)$

\begin{tabular}{lcc}
\hline \multicolumn{1}{c}{ Variable } & $\begin{array}{c}\text { Component } 1: \\
\text { Decision } \\
\text { Avoidance }\end{array}$ & $\begin{array}{c}\text { Component 2: } \\
\text { Egalitarianism }\end{array}$ \\
\hline $\begin{array}{l}\text { Eigenvalue } \\
\text { Percentage variance }\end{array}$ & 3.62 & 1.56 \\
Item & 36.2 & \\
I would rather not make & & \\
decisions regarding who & & \\
should receive or be denied & & \\
treatment in these kinds of & & \\
programs. & .81 & \\
I would feel awkward making \\
decisions about who should \\
receive versus be denied help. \\
I would gladly pay a couple of \\
dollars to avoid making \\
difficult decisions. \\
It would be painful for me to \\
make decisions about who \\
should receive versus be \\
denied help. \\
In principle, I think everyone \\
who needs treatment should \\
get it, regardless of how much \\
it costs society. \\
In principle, I believe everyone \\
who needs treatment should \\
get it, regardless of how much \\
it costs me personally. \\
I do not think everyone who \\
needs treatment is equally \\
deserving of government \\
assistance. \\
I do not think providing aid to \\
everyone who needs \\
treatment is a good use of \\
government funds. \\
\hline
\end{tabular}

significant unique variance in AZT budget allocations $(29.16 \%)$.

Even when RWA was entered first into the equation, it explained no significant variance in budget allocations. The correlational evidence (see Table 4) suggested that the effects of RWA were mediated by EE. Path analysis confirmed this interpretation (see Figure 1). Specifically, whereas RWA was uncorrelated with the amount allocated to AZT for AIDS patients, it was correlated with $E E$ (the set of variables that explained most of the variance in budget allocations). Thus, ideological beliefs were associated with different attributions for why AIDS patients needed help and the effectiveness of the AZT program that in turn predicted the funding provided to the AZT program.

\footnotetext{
${ }^{4}$ Location did not have any significant effects on dependent variables after taking political ideology (RWA) into account. Southern Illinois students were higher in RWA than Berkeley students, $t(158)=4.86, p<$ .01. Combining the samples created a reasonably normal distribution (skewness $=-.24$ ) with a mean RWA of 87.42 .
} 
Table 3

Average Budget Allocations to Different Programs in Millions of Dollars

\begin{tabular}{lc}
\hline \multicolumn{1}{c}{ Program } & Budget (in millions) \\
\hline Medicare & $17.23_{\mathrm{a}}$ \\
Women, Infants and Children Program & $15.06_{\mathrm{ab}}$ \\
Organ transplants & $13.04_{\mathrm{b}}$ \\
Healthy kids & $12.28_{\mathrm{b}}$ \\
Mental health & $11.6 \mathrm{l}_{\mathrm{b}}$ \\
Independent living & $11.14_{\mathrm{b}}$ \\
Family planning & $10.98_{\mathrm{b}}$ \\
Azidothymidine (AZT) for AIDS victims & $9.38_{\mathrm{bc}}$ \\
\hline
\end{tabular}

Note. Means without common subscripts were significantly different at $p<.05$.

\section{Willingness to Expand the Budget}

Do political ideology and perceptions of personal responsibility affect willingness to expand the budget to help everyone? More than half of the subjects $(57.8 \%)$ voted to increase the budget. Consistent with our hypothesis, people who voted to expand the resource pool to help all claimants were significantly lower in RWA $(M=87.32)$ than those who did not $(M=92.32)$, $F(1,162)=4.45, p<.05$.

Why do high scorers on RWA withhold assistance from people who need help? A "No" vote, in effect, hastened the death of AIDS patients. Analyses indicated that perceptions of high personal responsibility for needing help explained the most unique variance in ideological differences in voting behavior, followed by the desire to avoid making individual allocation decisions. Cost, egalitarianism, and efficiency had little independent effect on the decision to augment the resource pool, but when considered in isolation, both egalitarianism and efficiency emerged as significant covariates of the vote-authoritarianism relationship. Cost was not, however, a significant covariate. These analyses are described in more detail in the following paragraphs.

Personal cost. A 2 (Vote) $\times 2$ (Cost) analysis of variance revealed no ideological differences as a function of cost of expanding the resource pool ( $2 / 3$ of subjects' pay vs. no mention of

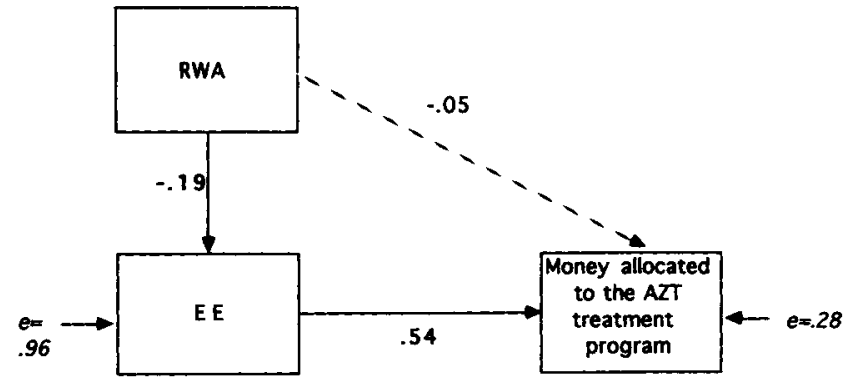

Figure 1. Path diagram indicating indirect effects of right-wing authoritarianism (RWA) on aid allocations. (Bold-faced path coefficients are significant. The dashed line represents the direct effect of RWA on allocations. $\mathrm{EE}$ = the external locus of responsibility and efficiency component, $\mathrm{AZT}=$ azidothymidine, and $\mathrm{e}=$ residuals. .

costs) on willingness to expand the resource pool to help all claimants; cost main effect: $F(1,162)=0.27$, $n s$; and Cost $\mathrm{X}$ Vote interaction: $F(1,162)=1.22$, ns. In other words, thriftiness is not a plausible explanation for ideological differences in willingness to provide public assistance.

Trade-off avoidance, value expression, and punitiveness. To investigate other explanations for the vote-ideology relationship, a multivariate analysis of covariance tested whether ideological differences disappeared when the covariates of egalitarianism, external-efficiency, personal responsibility, homosexual defensiveness, and avoidance of making individual level allocation decisions were taken into account either separately or simultaneously. Table 5 summarizes these results.

Analyses of covariance (ANCOVAs) with vote as the independent variable; RWA as the dependent variable; and external/ efficiency (EE), personal responsibility (PR), egalitarianism, decision avoidance, and homosexual defensiveness entered separately as covariates eliminated the observed differences in vote as a function of RWA. That is, when considered separately, each control variable explained significant variance in ideological differences in willingness to help all claimants, and each was sufficient to reduce the effects of RWA on vote to nonsignificance (see left column of Table 5).

Examining the variables as a set of covariates (i.e., entering

Table 4

Correlates of Budget Allocation to Azidothymidine (AZT) Program

\begin{tabular}{lcccccccc}
\hline \multicolumn{1}{c}{ Component } & 1 & 2 & 3 & 4 & 5 & 6 & 7 & 8 \\
\hline 1. Millions of dollars & - & & & & & & & \\
2. RWA & -.05 & - & & & & & \\
3. EE & $.53^{* *}$ & $-.19^{* *}$ & - & & & & \\
4. PR & -.09 & $.26^{*}$ & -.01 & - & & & \\
5. Experiential schematic-function & -.01 & -.01 & .00 & .12 & - & & \\
6. Social-expressive function & -.15 & $.21^{* *}$ & .05 & $.23^{* *}$ & $.20^{* *}$ & - & & \\
7. Defensive function & $-.18^{*}$ & $.47^{* *}$ & $-.17^{*}$ & $.33^{* *}$ & -.02 & $.41^{* *}$ & - & \\
8. Value-expressive function & -.09 & .11 & .03 & .05 & .06 & $.21^{* *}$ & $.15^{*}$ & - \\
\hline
\end{tabular}

Note. $\quad \mathrm{RWA}=$ Right-Wing Authoritarianism; $\mathrm{EE}=$ the external locus of responsibility and efficiency component; $P R=$ the internal locus of responsibility and blame component.

$* p<.05$. ** $p<.01$. 
Table 5

Standardized Regression Coefficients of Variables Explaining Ideological Differences in Willingness to Expand the Budget to Help All Claimants

\begin{tabular}{lcc}
\hline \multicolumn{1}{c}{ Covariate } & $\begin{array}{c}\text { Standardized } \beta \text { with } \\
\text { separate ANCOVA } \\
\text { analysis }\end{array}$ & $\begin{array}{c}\text { Standardized } \beta \\
\text { with analysis of } \\
\text { covariates } \\
\text { as a set }\end{array}$ \\
\hline External-efficiency & $-.23^{* *}$ & -.04 \\
Personal responsibility & $.46^{* *}$ & $.41^{* *}$ \\
Egalitarianism & $-.14^{*}$ & -.09 \\
Avoidance & $-.23^{*}$ & $-.16^{*}$ \\
Homosexual defensiveness & $.27^{*}$ & .07 \\
\hline
\end{tabular}

Note. ANCOVA $=$ analysis of covariance.

${ }^{*} p<.05 .{ }^{* *} p<.01$.

all of the covariates in a single ANCOVA) yielded a significant overall effect, $F(5,154)=8.78, p<.001$, and a nonsignificant effect for RWA on vote, $F(1,154)=.04$, ns. Examination of the unique variance contributed by each covariate indicated that attributions of personal responsibility and blame, followed by the desire to avoid making individual allocation decisions, best explained ideological differences in willingness to expand the budget (see right column of Table 5). High RWA (conservatism) was associated with higher perceptions of personal responsibility among AIDS patients, $r=0.28, p<.001$, and lower decisional avoidance, $r=-0.23, p<.001$.

\section{Discussion}

The results of Study 1 indicated that conservatives are more tolerant of scarcity and less likely to alleviate shortages than liberals. It is interesting to note the comparatively minor role of homosexual defensiveness in willingness to help AIDS patients, a result consistent with previous research. Instead, ideological differences in willingness to help are best explained by both attributions of responsibility and the desire to avoid deciding who should be helped. Conservatives made more internal-controllable attributions for why claimants needed help. They perceived AIDS patients as "people who just want a free-ride" and who "do not try hard enough to help themselves"; perceptions that were independent of the perceived effectiveness of the AZT program in prolonging life, and of the cost-effectiveness of the AZT program. Given that assessments of high personal responsibility factored out separately from perceived program effectiveness and cost efficiency, the punitiveness hypothesis gained increased support as an underlying distinct motive for conservative allocation behavior.

These results contribute to our understanding of the intense policy debates surrounding AIDS treatment programs. Although previous research has linked attributions of responsibility to derogation of and social distancing from AIDS patients and demonstrated that under scarcity allocators withhold assistance from individual AIDS patients perceived to be responsible for their plight, there has been no clear demonstration that attributions of personal responsibility lead to withholding resources from AIDS patients at a programmatic level. The re- sults of this study indicated that not only are attributions of responsibility linked to withholding treatment from individual AIDS patients, but conservatives' unwillingness to expand spending on an AZT program is best explained by attributions of responsibility to AIDS patients as a class.

Liberals showed almost the opposite pattern of results. Liberals found the prospect of making individual allocation decisions to be both emotionally painful and socially awkward; this is consistent with the idea that liberals find it especially distasteful to trade lives for money. Liberals were less likely to hold AIDS patients as a class responsible for their illness, and more likely to expand the resource pool to help all claimants in order to avoid deciding who should go without assistance. In short, ideological differences in willingness to expand the resource pool seemed motivated by a combination of conservative punitiveness and liberal decision avoidance.

Studies 2 and 3 explored these possible explanations for ideological differences in greater detail. For example, reluctance to take on the role of rationing scarce resources may be rooted in either a desire to avoid emotionally painful trade-offs or cognitive laziness. Similarly, conservative withholding of abundant resources from AIDS patients may be motivated by either a desire to deter others from breaking social norms or a desire to uphold "traditional family values" for the (presumed) longterm benefit of the community, rather than pure punitiveness.

\section{Liberal Egalitarianism: Thoughtful Moral Judgment or Ideological Reflex?}

The previous study indicated that liberals felt more awkward about deciding which individual claimants should receive assistance than did conservatives, thus supporting the idea that liberals wanted to avoid trading off important values. One hypothesis traces this pattern of decision avoidance to cognitive laziness and the desire to retreat to simple ideological formulas in solving vexing social problems. In short, liberals are, to borrow Langer's phrase, "mindlessly" egalitarian. Equal allocations certainly have the virtue (from a cognitive miser's perspective) of simplicity; they do not require carefully scrutinizing competing claims on resources, one simply helps everyone.

Moreover, the mindlessness hypothesis is consistent with considerable research that indicates much behavior, even complex social interaction, can be enacted without attending to it (Abelson, 1981; Langer, 1978), and that people have to be spurred by unexpected events to engage in detailed attributional analysis (Wong \& Weiner, 1981). Conservatives may therefore follow a script that dictates "reward hard workers" and "punish freeriders," a script that works well, regardless of resource scarcity. In a similar vein, liberals may plug in an egalitarian script whenever there are adequate public resources to satisfy demand.

An alternative hypothesis is that liberals do not simply stop thinking when public resources exceed public needs. Liberals still pay attention to individual claimants and engage in a balanced, integratively complex weighing of conflicting alternatives (see Tetlock's, 1986, value pluralism model of ideological reasoning). The reluctance of liberals to make individual allocation decisions is rooted in painful awareness of the competing values at stake, not in a lazy preference for relying on overlearned ideological habits of thought. 


\section{Study 2}

To investigate the competing portraits of liberals, Study 2 varied the amount of thought subjects were required to devote to individual claimants before making allocations. Two resource domains were included to examine the generalizability of results across policy domains: AZT for AIDS patients, and vocational training for the unemployed. In the thought condition, subjects responded to detailed rating scales for each claimant, including questions that primed attributional analysis for why claimants need assistance. In the no-thought condition, subjects simply read descriptions of claimants without making any ratings (in a replication of Skitka \& Tetlock's, 1992, Study 2) before making their allocation decisions.

According to the mindlessness hypothesis, the allocations of liberals should depend on whether they are compelled to think about individual claimant characteristics. Under no scarcity, liberals in the thought condition will more frequently deny assistance to claimants with internal-controllable needs than in the no-thought condition, but will not differ in their willingness to help other claimants (i.e., claimants with internal-uncontrollable, external-controllable, and external-uncontrollable causes of need). Conservatives are predicted to deny internal-controllable claimants assistance more than other claimants regardless of whether they are prompted to think about characteristics of individuals.

In contrast, the thoughtfulness hypothesis predicts no difference in liberals' allocations across thought conditions. Liberals will tend to help everyone under both thought conditions, whereas conservatives will deny aid to internal-controllable claimants under both conditions.

\section{Study 2}

\section{Method}

\section{Subjects}

Subjects who participated in this study received partial fulfillment of requirements for a course in introductory psychology. Two different locations were used to increase the range of political ideology: Southern Illinois University $(N=92)$ and the University of California, Berkeley $(N=40)$. None of these subjects had participated in Study 1 .

\section{AZT Claimants}

We asked subjects to allocate AZT to AIDS patients who varied in sexual preference (homosexual vs. heterosexual), in treatment effectiveness (treatment would extend person's life 1-4 years) and in locus of responsibility for their disease. These loci included the following: internal-controllable (IC)—contracted AIDS from engaging in high-risk sexual behavior even after learning how AIDS is transmitted; internal-uncontrollable (IU) - modified sexual behavior after learning how AIDS is transmitted, but had been exposed to the HIV virus before AIDS was known to be a sexually transmitted disease; external-controllable (EC)-contracted AIDS from a long-term, but unfaithful partner; external-uncontrollable (EU)-blood transfusion before the AIDS antibody test was developed to screen blood. In other words, claimant descriptions varied in a $2 \times 2 \times 4$ design yielding 16 claimants to whom subjects could give or deny public resources. Except for the within-subject manipulation of target sexual preference, these claimant descriptions were the same as those used in the Skitka and Tetlock (1992) study.

\section{Vocational Training Claimants}

Subjects also allocated vocational training to unemployed workers who varied in the locus of responsibility for being unemployed (IC: lost previous job because of poor effort; IU-physical handicap; EC: laidoff from a profitable firm that wanted to avoid unionization; EU-poor economy) and two operationalizations of efficiency: the claimant's aptitude for the job for which training was available (high or moderate scores on a job aptitude test), and current market demand for that position (50-75\% probability of getting a job if training is provided). In other words, claimant descriptions varied in a $4 \times 2 \times 2$ design yielding 16 claimants whom subjects could chose to help.

Mindlessness measure. As another measure of mindless egalitarianism, an additional claimant was listed on each subject's selection sheet ("Person Q" when no Person Q is described in the claimant pool). If liberals are mindlessly egalitarian, we would expect that they will be more indiscriminately generous; that is, a mindless egalitarian should check "give" for all claimants including Person Q, although no Person $\mathrm{Q}$ was described in the claimant pool. Person $\mathrm{Q}$ also provided an additional check on whether the thought manipulation worked. Forcing people to think should reduce Person Q checks.

Personality/Ideology measures. Subjects completed a packet of personality and attitudinal measures, including Altemeyer's (1988) RWA scale, Katz and Hass's (1988) humanitarian scale, and Rasinki's (1987) personal values (egalitarianism/proportionality) scales, and a single item, self-reported liberalism-conservatism measure on a 1 (extremely conservative) to 10 (extremely liberal) scale. Principal components analysis of these measures with a varimax rotation created a reduced set of measures of political ideology. ${ }^{5}$ Analysis revealed two internally consistent and reliable components. The first component reflected a combination of high right-wing authoritarianism, self-reported conservatism, and low egalitarianism (on the Rasinski scale) (eigenvalue $=$ 2.03). The second component reflected high humanism (Katz \& Hass scale) and low proportionality (eigenvalue $=1.13$ ). The first component was retained as the best representation of political ideology, and was consistent with the cognitive conservatism resonance found in earlier research (e.g., Carroll et al., 1987; Skitka \& Tetlock, 1992) ${ }^{6}$ Component scores (calculated using the regression method) were used as indices of political ideology. Subjects scoring above the 66th percentile were designated conservatives, subjects scoring between the 33rd and 66th percentiles were designated moderates, and subjects scoring below the 33 rd percentile were called liberals. In addition, Herek's Functional Attitudes Toward Gays and Lesbians Scale (Herek, 1987) was used to measure homosexual defensiveness.

\section{Procedure}

Subjects participated in small groups of 3 to 15 . Subjects were informed that they were participating in a study of how people make fair allocation decisions, that their task was to fll out several questionnaires, and that their confidentiality would be protected. Subjects made allocations to claimants in both the vocational training and AZT resource domains, but in only one thought condition. Half of the subjects made allocations in the unemployment policy domain first; the other half made allocations in the AIDS policy domain first.

Subjects assigned to the thought condition were told to read the descriptions of the 16 claimants per policy domain and to respond to 13

\footnotetext{
${ }^{5}$ Using an oblimin rotation (allowing components to correlate) did not change the number of components identified or the rank ordering of component loadings.

${ }^{6}$ The second component was less clearly an index of ideology separate from distributive value endorsement, and did not yield any significant effects in subsequent analysis.
} 
scaled questions assessing their perceptions of these claimants (e.g., degree of personal responsibility for needing help, sympathy, pity, anger, disgust aroused by claimants, relative deservingness for resources; unfairness if claimant does not receive assistance). They were also told that upon completion of these ratings that they could select as many (or as few) claimants as they thought should receive assistance in the program. Subjects rated all the claimants in one policy domain, selected those whom they wished to receive assistance, rated the claimants in the other policy domain, and then selected those whom they wished to receive assistance.

Subjects assigned to the no-thought condition were told to read the descriptions of the 16 claimants, and then to select as many (or as few) claimants as they wanted to assist in the program. Subjects read descriptions in one domain, made their selections, and then moved on to the other policy domain.

As a check for the thought manipulation, all subjects evaluated how attentively and carefully they evaluated each claimant. We also collected manipulation checks for the previously untested vocational training descriptions. Specifically, after making all their allocations, subjects rated the extent to which each cause of need was preventable (either by the target or someone else); internal to the person (e.g., the person's body, behavior, or personality) as opposed to external (e.g., society, the economy); and how efficient a use of resources it was to provide vocational training to people varying in job aptitude and market demand. An additional questionnaire assessed perceptions of the allocation task on 1 to 7 scales, including self-perceptions of the harshness of one's allocations compared to other people, decision avoidance and awkwardness, and perceived qualifications for making these kinds of decisions. Subjects then completed the personality and attitudinal scales, and were fully debriefed.

\section{Results}

\section{Thought Manipulation Check}

Subjects in the thought condition reported that they gave more attentive consideration to individual claimants than subjects in the no-thought condition, $t(130)=-3.79, p<.01$, with neither a main effect for political ideology, nor an interaction between ideology and thought condition. ${ }^{7}$ Both liberals and conservatives gave more careful consideration to individual claimants before allocating in the thought condition than in the no-thought condition. ${ }^{8}$

In addition, if the thought manipulation was successful, we expected a decrease in Person Q selections in the thought, as compared to the no-thought conditions. In support of the effectiveness of the thought manipulation, subjects were less likely to choose Person $\mathrm{Q}$ in the thought conditions than in the no-thought conditions, in both the $\mathrm{AZT}, \chi^{2}(1, N=132)=4.20$, $p<.05$, and vocational training, $\chi^{2}(1, N=132)=5.13, p<.05$, domains. In the vocational domain, $37.1 \%$ of the subjects in the no-thought condition assisted Person $\mathrm{Q}$ as compared to only $20.3 \%$ in the thought condition. Similarly, Person $Q$ selections for AZT decreased by $17 \%$ in the thought $(21.5 \%)$ as compared to the no-thought condition (38.5\%). Together, these manipulation checks indicated that subjects in the thought condition more carefully evaluated the claimants and more carefully made decisions.

\section{AZT Allocations}

Results indicated that $54 \%$ of the subjects assisted all AZT claimants (givers), whereas $46 \%$ denied assistance to at least one claimant (deniers). Consistent with previous results (see Skitka \& Tetlock, 1992), givers were more liberal than deniers, $t(130)$ $=-3.43, p<.01$.

The effects of thought on willingness to help claimants. No effects emerged for the thought manipulation. Liberals (and conservatives for that matter) were unaffected by whether they were required to think carefully about claimants before allocating AZT to AIDS patients. Despite the thought condition, $77 \%$ of the liberals chose all of the claimants to receive aid, and $61 \%$ of conservatives denied aid to at least one claimant. Moderates were almost equally likely to help all claimants $(51 \%)$ and to deny aid to at least one claimant $(49 \%)$.

Analysis of the 2 (thought) $\times 4$ (locus of responsibility) $\times$ 2 (efficiency) $\times 2$ (target sexual preference) $\times 3$ (ideology) mixed ANOVA revealed no effects for the thought manipulation, but significant main effects for political ideology: $F(2,131)=8.53$, $p<.01$; target sexual preference: $F(1,131)=15.72, p<.01$; locus of responsibility: $F(3,393)=59.53, p<.01$; and efficiency: $F(1,131)=8.01, p<.01$. Liberals chose, on average, one more claimant to receive assistance than either moderates or conservatives (no significant difference between the latter two groups based on Tukey post hoc tests). Heterosexual claimants were chosen more ( $M=7.14$ of a total of 8$)$ than homosexual claimants $(M=6.54)$, and IC claimants were chosen less $(M=$ 2.55 of 4$)$ than IU $(M=3.66)$, EC $(M=3.82)$, or EU $(M=$ 3.82 ) claimants (there were no significant differences between the latter 3 sets of claimants). Finally, claimants for whom treatment was expected to be more effective were chosen to receive more AZT ( $M=6.98$ of 8$)$ than those with low treatment effectiveness $(M=6.71)$.

Beyond these main effects, two interactive effects on choice were noted. Political ideology interacted with target sexual preference, $F(2,131)=7.57, p<.01$, and locus of responsibility, $F(6,393)=2.94, p<.01$. Analysis of simple effects indicated that liberals were equally likely to select homosexual $(M=7.49)$ and heterosexual $(M=7.60)$ claimants, $F(1,130)=1.61, n s$, but moderates and conservatives were more likely to select heterosexual than homosexual claimants; $F(1,130)=8.17, p<.01$ and $F(1,130)=258.61, p<.01$, respectively. Moderates chose on average 6.69 homosexuals to receive assistance, as compared to 6.94 heterosexuals, and conservatives chose on average 5.45 homosexuals as compared to 6.91 heterosexuals. Controlling for homosexual defensiveness in an analysis of covariance did not change these results.

In further analysis of the Political Ideology $\times$ Locus of Responsibility interaction (i.e., examination of partial interactions), moderates did not differ from either liberals or conservatives. Instead, the interaction effect was the result of diverging reactions of liberals and conservatives. Further analysis indicated that liberals did not differentially assist claimants as a function of locus of responsibility, $F(3,393)=1.74$, ns (see Ta-

\footnotetext{
${ }^{7}$ No significant effects emerged for order of policy domain allocations (AZT vs. vocational training), nor did any significant effects emerge for location (Southern Illinois University at Edwardsville vs. Berkeley) once political ideology was controlled.

${ }^{8}$ Manipulation checks for the locus of responsibility manipulations (i.e., descriptions of AIDS patients) are described in detail in Skitka and Tetlock (1992).
} 
ble 6 for more detail). In other words, liberals were equally likely to assist all claimants, regardless of why they needed assistance. A significant simple main effect did emerge for locus of responsibility with conservatives, $F(3,393)=8.15, p<.01$. Conservatives were equally likely to help claimants with IU, EC, or EU causes of need, $F(2,393)=0.74, n s$, but were less likely to help IC claimants relative to IU, EC, or EU claimants, $F(1,393)=$ $15.31, p<.01$.

In summary, the pattern of results matches the portrait of a thoughtful, not mindless, liberal egalitarian. Liberals helped all claimants regardless of thought condition, whereas conservatives withheld aid from homosexuals and claimants who were personally responsible for needing assistance.

An additional measure of mindlessness: Person $Q$. As an additional measure of mindlessness, we examined reactions to the extra claimant on subjects' selection sheet, who was not described in the claimant pool (i.e., Person Q). If liberals were mindlessly egalitarian, we would expect them to be more indiscriminately generous. A mindless egalitarian should check "give" for all claimants, including the fictitious Person Q. If allocators carefully considered each claimants' relative worth before allocating, Person Q will be noticed as a "mistake" on the selection worksheet. In further refutation of the mindlessness hypothesis, analysis indicated no effects for political ideology on whether subjects selected, denied, or noticed the incorrect insertion of Person Q, main effect: $F(2,129)=2.71, n s$; and interaction with thought condition: $F(2,129)=0.42$, $n s$. It could be argued that if both liberals and conservatives are responding mindlessly, then there should be no ideology effect but a consistently high baseline of support for Person $\mathrm{Q}$. The results here are mixed. In the no-thought condition, $39.4 \%$ of the subjects selected Person $Q$ to receive AZT, suggesting considerable but not overwhelming mindlessness.

\section{Vocational Training Allocations: Manipulation Checks}

Locus of responsibility. As is frequently the case (e.g., Russell, McAuley, \& Tarico, 1987; Weiner, 1986), attributions of locus and control of need were not independent, but rather had significant interactive effects of locus and control on perceptions of preventability, $F(1,131)=77.53, p<.01$, and locus, $F(1$, $130)=32.70, p<.01$. Analysis of simple effects with the con-

Table 6

Average Number of Claimants Chosen to Receive Assistance as a Function of Locus of Responsibility and Political Ideology of the Allocator

\begin{tabular}{lccc}
\hline Locus of responsibility & Conservatives & Moderates & Liberals \\
\hline Azidothymidine (AZT) & & & \\
$\quad$ Internal-controllable & 2.00 & 2.43 & 3.26 \\
$\quad$ Internal-uncontrollable & 3.39 & 3.72 & 3.88 \\
External-controllable & 3.27 & 3.74 & 3.95 \\
$\quad$ External-uncontrollable & 3.70 & 3.76 & 4.00 \\
Vocational training & & & \\
Internal-controllable & 1.07 & 1.24 & 1.95 \\
Internal-uncontrollable & 3.80 & 3.66 & 3.93 \\
External-controllable & 3.84 & 3.72 & 3.79 \\
External-uncontrollable & 3.68 & 3.70 & 3.93 \\
\hline
\end{tabular}

trollability manipulation check indicated no difference in the perceived preventability of the uncontrollable causes, $F(1,130)$ $=3.32, n s$, but internal-controllable causes were seen as more preventable than external-controllable causes, $F(1,130)=$ 73.06, $p<.01$. Of most importance here, controllable causes were seen as more preventable than uncontrollable causes at both levels of locus. Analysis of simple effects indicated no difference in perceived externality of the external locus manipulations, $F(1,131)=4.47, n s$, but internal-controllable causes were seen as more internal than internal-uncontrollable causes, $F(1,131)=35.65, p<.01$. Again however, internal causes were seen as more internal than external causes at both levels of control.

Efficiency. The manipulation checks for the two efficiency manipulations, job aptitude and market demand, revealed the intended perceptual effects. When asked how efficient a use of resources it would be to provide vocational training to claimants with high versus moderate job aptitude test scores, highaptitude claimants received higher efficiency ratings, as revealed by a dependent $t$ test, $t(131)=12.36, p<.01$. Similarly, subjects rated providing job training to claimants with a $75 \%$ chance of procuring a job as a more efficient use of resources than providing training to claimants with a $50 \%$ chance of procuring a job, $t(131)=17.82, p<.01$.

The effects of thought on willingness to help claimants. In contrast to the AIDS policy domain, only $22 \%$ of all the subjects (37\% of which were liberals) assisted all claimants for vocational training. As expected, however, givers were more liberal than deniers, $t(130)=-3.71, p<.01$. Analysis of the 3 (political ideology) $\times 4$ (locus of responsibility) $\times 2$ (market demand) $\times 2$ (job aptitude) mixed ANOVA revealed no effects for the thought manipulation. Main effects were observed for political ideology, locus of responsibility, job aptitude, and market demand; $F(2$, $131)=4.38, p<.05 ; F(3,393)=211.18, p<.01 ; F(1,131)=$ $17.26, p<.01$; and $F(1,131)=16.21, p<.01$, respectively. Tukey tests indicated that, analogous to the AIDS policy domain, conservatives and moderates did not differ in the number of claimants helped ( $M=12.39$ and 12.32 of the 16 claimants, respectively), but helped fewer claimants than liberals ( $M=$ 13.60). IC claimants for vocational training received less assistance (chosen on average 1.4 of a possible 4 ) than IU, EC, or EU claimants ( $M=3.80$; no significant differences among these three sets of claimants). Claimants with high job aptitude received more assistance ( $M=6.56$ of 8$)$ than claimants with moderate job aptitude $(M=6.16)$, and claimants with a $75 \%$ chance of procuring a job after training received more assistance $(M=6.84$ of 8$)$ than those with only a $50 \%$ chance of procuring a job after training $(M=6.08)$.

Again, results did not support the mindlessness hypothesis. Making liberals and conservatives think carefully about claimants before allocating did not affect their willingness to help. Paralleling the results in the AIDS domain, the only significant interaction was political ideology by locus of responsibility. Again, moderates did not differ significantly from either liberals or conservatives. Rather, the source of the interaction was the sharp divergence in liberals' and conservatives' willingness to help claimants as a function of locus of responsibility. Analysis revealed significant simple main effects for locus of responsibil- 
ity with both liberals, $F(3,393)=11.95, p<.01$, and conservatives, $F(3,393)=25.52, p<.01$ (see bottom of Table 4 ).

Analysis of simple effects indicated that liberals were less likely to help IC claimants than IU, EC, or EU claimants, $F(1$, $393)=23.86, p<.01$, with no significant differences among the latter three sets of claimants, $F(2,393)=0.09, p<.01$. The results for conservatives paralleled those for liberals. IC claimants received less help from conservatives than did IU, EC, or EU claimants, $F(1,393)=52.94, p<.01$, with no differences among the three latter sets of claimants, $F(2,393)=0.18$, ns. No significant simple effects emerged for political ideology in willingness to help IU, EC, or EU claimants; $F(1,393)=0.12$, $n s ; F(1,393)=0.02, n s$; and $F(1,393)=0.40, n s$, respectively. Liberals and conservatives differed only in their willingness to help claimants who were personally responsible for being unemployed, $F(1,393)=5.07, p<.05$. Liberals assisted more personally responsible claimants $(M=1.95$ of 4$)$ than conservatives $(M=1.06)$. In other words, consistent with the AZT results, conservatives withheld more assistance from personally responsible claimants than liberals. Liberals, though, were unenthusiastic about helping personally responsible claimants in the unemployment domain.

Person $Q$. We again included a Person $\mathrm{Q}$ on the selection worksheet as an additional test of the mindlessness hypothesis. Again, contrary to this hypothesis, no significant ideological differences emerged in whether this fictitious person was given or denied assistance, or noticed as a mistake, regardless of thought condition; main effect: $F(2,126)=0.82$, ns, and interaction with thought condition: $F(2,126)=0.81$, ns. Person $Q$ was provided vocational training by $29.1 \%$ of the subjects.

\section{Comparing the AIDS and Unemployment Policy Domains}

Because the data from the AIDS and unemployment policy domains came from the same subjects, we could explore whether ideology and locus of responsibility interacted across domains. The three-way interaction of political ideology, locus of responsibility, and domain was not significant, indicating that the Ideology $\times$ Locus of Responsibility interaction replicates well across domains. The Domain $\times$ Locus of Responsibility interaction was significant, $F(3,393)=36.51$, and the marginal effect of the Ideology $\times$ Domain interaction deserved attention, $F(1,131)=3.04, p=.05$. Follow-up simple comparisons yielded two major results: (a) personally responsible claimants were more likely to receive $\mathrm{AZT}$ treatment than vocational training, and (b) conservatives' willingness to help was stable across domains (they generally denied personally responsible claimants assistance, regardless of domain). In comparison, liberals were less likely to provide vocational training than AZT treatment (especially to personally responsible claimants), but provided more of both kinds of aid than did conservatives.

\section{Perceptions of the Task}

In addition to allocating public assistance, subjects responded to several questions regarding their perceptions of the task. We were particularly interested in the relationship between political ideology and how comfortable people felt making these kinds of allocation decisions, as well as whether conservatives and liberals were aware that they were more or less generous than other allocators. Table 7 summarizes the results.

Consistent with their actual allocation behavior, conservatives believed that they were harsher than other allocators in their allocation decisions. In addition, it is interesting to note the correlation of ideology with self-reports of mindfulness. In contrast to the portrait of liberals as mindlessly or blindly egalitarian, liberals reported that they gave more careful consideration to individual claimants than conservatives reported they gave. Consistent with the results of Study 1, liberalism was also associated with greater decision avoidance and feelings of awkwardness and discomfort with the allocator role. However, there was no relationship of ideology to whether subjects felt qualified to make these kinds of allocation decisions.

\section{Discussion}

We were interested in whether liberals would be less egalitarian and generous if forced to think about why individual claimants needed assistance. Even when compelled to focus on each claimant's relative deservingness and reasons for needing assistance, however, liberals tended to allocate resources equally to all claimants under no scarcity. Conservatives, in contrast, withheld help from homosexual AIDS patients and those personally responsible for their predicament.

Because the thought manipulation did not affect liberals' willingness to help all claimants, we can conclude that making liberals think carefully about individual claimants does not change their willingness to help all claimants under no scarcity. The conclusion against mindlessness however entails accepting the null hypothesis. Our interpretation of the results is bolstered by several observations: (a) Two very different manipulation checks (self-reported thought and Person Q checks) indicated that subjects gave more careful thought to individual claimants under the thought than no-thought conditions; (b) The overall degree of mindlessness (indicated by Person $Q$ checks) was not so large that liberals (or conservatives) could be plausibly accused of never thinking, regardless of attempts to stimulate thought; (c) The study replicated the basic findings of ideological differences in allocation decisions under no scarcity (i.e., liberals help all claimants, whereas conservatives withhold help

Table 7

Principal Components Analysis of Affective Reactions to Claimants

\begin{tabular}{lcc}
\hline \multicolumn{1}{c}{ Variable } & Positive affect & Negative affect \\
\hline Eigenvalue & 3.60 & 3.24 \\
Percentage of variance & 45.0 & 40.7 \\
Reaction & & \\
Compassion & .98 & \\
Sympathy & .98 & \\
Generosity & .94 & .94 \\
Pity & .85 & .94 \\
Punitive & & .92 \\
Disgust & & .91 \\
Distaste & & \\
Moral outrage & & \\
\hline
\end{tabular}


from those responsible for their predicament). The experiment was thus sufficiently sensitive to be able to detect any well-established effects of thought on policy preferences; and (d) the finding on ideological differences replicated across two very different policy domains, AZT and vocational training. In summary, although the mindlessness hypothesis cannot be completely ruled out, we can marshal a persuasive set of counter arguments against it. The burden of proof has shifted to those who would characterize the judgment policies of liberals as mindless (cf. Greenwald, 1975, on the power of null hypothesis results to shift burdens of proof).

In addition, because there were no interactive effects of political ideology with the efficacy of assisting claimants (i.e., how long AZT would extend each person's life in the AIDS policy domain, or extent of market demand and job aptitude in the unemployment domain), we cannot argue that liberals were oblivious to efficiency concerns. Whereas most liberals allocated resources equally to all claimants who needed assistance in the AIDS domain, this result was tempered when the goal of the social system (the labor market) was to increase productivity. In the unemployment domain, liberals and conservatives were equally likely to withhold assistance from claimants if either job aptitude or market demand were low (efficiency concerns).

Although the major goal of the thought studies was to investigate flattering and unflattering portraits of liberals, we also learned more about conservatives. Conservatives appear to withhold assistance from people responsible for their plight because of a desire to punish or deter norm violators rather than to maximize efficiency. Support for this interpretation is based on the result that conservatives not only consistently refused to help personally responsible claimants, but they also discriminated against homosexual claimants of AZT; a result not weakened by controlling homosexual defensiveness or degree of personal responsibility for contracting the disease. Conservatives' reactions to homosexual claimants cannot therefore be explained by invoking homophobia. In light of the other results (particularly, the absence of ideology effects on efficiency, liberals and conservatives alike assisted claimants who could be helped and denied assistance to those who could not), the most plausible interpretation is that conservatives were indeed motivated by the desire to either deter or punish violators of traditional values (e.g., the work ethic and heterosexual coupling in family units). Study 3 was designed to investigate the extent to which conservatives are motivated by deterrence versus punitiveness when they withhold assistance from claimants under no scarcity.

\section{Conservative Withholding: Punitive or Prudent?}

The thought studies explored alternative explanations for why liberals help all claimants under no scarcity. Now we pose the mirror-image question: Why do conservatives refuse to help everyone when there are sufficient resources to do so? In the next study we tested two possible explanations for the judgment policies of conservatives:

1. General deterrence and creating incentives for self-reliance. It is rational from a societal perspective to encourage people to take care of themselves by promoting a fear of falling through the safety net if they misbehave (see also Baron, 1993). As John Rockefeller is reputed to have once said, capitalism without poverty is like Christianity without Hell. In the name of efficiency and self-reliance, conservatives feel obligated to set an example by withholding aid from people personally responsible for their plight.

2. Punitiveness. Conservatives not only want to punish norm violators, they feel morally outraged by them. It is very disturbing for conservatives (whose lives are so carefully structured by the self-control and hard work they believe it takes to achieve success) to see others obtain comfort without the attendant sacrifices (Altemeyer, 1988; Bobo, 1983; Carroll et al., 1987). The election imagery of the welfare cheat in his or her Cadillac, according to this perspective, does not arouse merely mild annoyance among conservatives, it brings them to the boiling point. They are livid that anyone should free-ride at their expense. But what are the limits on this hostile response? Are conservatives so outraged by free-riders that they wish to punish them even after they reform?

To distinguish the deterrence and punitiveness hypotheses, we need to examine conservatives' emotional and policy reactions to personally responsible claimants who have reformed. The punitiveness hypothesis predicts that conservatives will withhold assistance from personally responsible claimants, even if they have reformed. According to this hypothesis, the point is not only to deter misconduct, but to express moral outrage and to reassure oneself that one's own sacrifices have not been in vain. The cold, purely cognitive, deter rence hypothesis can take two distinct forms. One allows for second chances; the other does not. The second-chance hypothesis predicts that if allocators are convinced that personally responsible claimants have really reformed and learned their lesson, the repenters deserve to be rewarded and reintegrated into the moral community. The underlying logic is that other free-riders will witness this reward contingency, and be inspired to change their behavior as well. The no-second-chances version of the deterrence hypothesis proposes that conservatives withhold assistance from reformed claimants not out of punitiveness, but because they believe allowing second chances undermines motivation to do well the first time around. In this view, conservatives do not withhold assistance to express moral outrage; rather, they do so in a dispassionate way to uphold their principled commitment to the idea that no society can survive if people are allowed to violate social contracts and norms with impunity (see Jencks, 1992; Murray, 1984).

\section{Reactions to Reformed Personally Responsible AIDS Patients}

Schwarzer and Weiner (1991) studied reactions to AIDS patients who varied in their responsibility for contracting AIDS, and in how well they coped with the onset of the disease. Some were described as coping well (dramatic changes in lifestyle or reformed) and others were described as coping poorly (no lifestyle changes or unreformed). Subjects blamed all personally responsible patients, regardless of the lifestyle change manipulation. However, subjects reported increased pity for personally responsible claimants who had changed their lifestyle. Because affect mediates the relationship between attributions of respon- 
sibility and perceptions of deservingness and helping behavior (e.g., Betancourt, 1990; Weiner, 1986), these results hint that people (perhaps especially conservatives), may be more likely to help personally responsible claimants who reform, a result consistent with the second-chance version of the deterrence hypothesis.

We designed Study 3 to differentiate between the deterrence and punitiveness hypotheses more decisively. The secondchance version of the deterrence hypothesis predicts that under no scarcity liberals and conservatives alike will help reformed claimants to the same degree as claimants who were not personally responsible for needing assistance (i.e., IU, EC, and EU claimants). Liberals and conservatives will diverge only when confronted by internal-controllable claimants who have not reformed. Based on our previous results, it is anticipated that liberals will be more likely to help unrepentant personally responsible claimants than will conservatives.

The punitiveness hypothesis also predicts that under no scarcity liberals will be more willing to help both reformed and nonreformed personally responsible claimants than will conservatives (i.e., liberals will be more likely to help everyone). However, conservatives will deny assistance to claimants who are personally responsible for needing assistance, regardless of whether they have reformed, and will help only claimants with IU, EC, or EU causes of need. According to the punitiveness hypothesis, negative affect (e.g., anger, contempt, even disgust toward personally responsible claimants) mediates the relationship between attributions and allocation decisions. Conservatives are expected to experience a strong emotional antipathy toward norm violators (i.e., people who are personally responsible for their predicament), that in turn predisposes them to reject public assistance for these claimants.

The no-second-chances version of deterrence predicts a similar pattern of allocation outcomes as the punitiveness hypothesis, but without the mediational role of negative affect. Conservatives, in this view, simply think it is bad public policy to give second chances. It puts us on a slippery slope (why not third or fourth chances?) and it reduces incentives to do the right thing the first time around. Forgiveness need not be a virtue, it can be a vice. It often means that those who worked hard and resisted temptation wind up subsidizing the indolent and self-indulgent. According to this perspective, conservatives' allocation decisions are motivated by the belief that for any society to function, checks and balances on socially appropriate behavior need to be enforced. Psychologists have long recognized the power of reward-punishment contingencies of this sort; the no-secondchances version of the deterrence hypothesis suggests that conservatives rationally apply these principles to promote the good of society.

\section{Study 3}

\section{Method}

\section{Subjects}

Subjects who participated in this study received partial fulfillment of requirements for a course in introductory psychology. Two different locations were used to increase the range of political ideology: Southern
Illinois University $(N=23)$ and the University of California, Berkeley $(N=19)$. None of the subjects participated in our earlier studies.

\section{Vocational Training Claimants}

The targets for vocational training from Study 2 were used as the stimulus materials, with two changes: (a) an extra internal-controllable claimant was added (In addition to the "loafer," we added an "alcoholic" " "this person lost his or her most recent job because of an alcohol problem"]); and (b) the within-subjects manipulation of reform was added. Some internal-controllable claimants were described as reformed (e.g., the person who lost his or her job because of an alcoholrelated problem has now "successfully quit drinking and regularly attends Alcoholics Anonymous meetings"), whereas another set did not mention reform. These changes resulted in a pool of 28 claimants, derived from a Locus of Responsibility (7: IC-alcoholic, IC-loafer, ICalcoholic-reformed, IC-loafer-reformed, IU, EC, EU) $\times$ Market Demand (2) $\times$ Job Aptitude (2) design.

The primary dependent measure was whether subjects chose claimants to receive resources under no scarcity. Subjects also rated affective reactions toward claimants before making their allocation decisions (e.g., disgust, pity, compassion, distaste, sympathy, anger, generosity, and punitiveness) on 1 to 9 scales. These scale items were reduced in a principal components analysis (see Table 8 for more detail) to two independent, internally cohesive and identifiable components reflecting negative (disgust, distaste, anger, and punitiveness; Cronbach's $\alpha=.93$ ) and positive affect (sympathy, compassion, pity, and generosity; Cronbach's $\alpha=.96$ ). Component scores were calculated using the regression method.

\section{Procedure}

The subjects who participated were told that the study will investigate how people make fair allocations of resources and were assured that all their responses would be confidential and nonidentifiable. Subjects then role-played allocators of vocational training to unemployed claimants. Half of the subjects completed manipulation checks (credibility of reform as assessed by two items; e.g., possibility for a loafer to turn over a new leaf and the odds of this person successfully reforming) at the beginning of the experiment, and the other half completed these measures after the experiment.

Subjects completed the same packet of personality and attitudinal measures as used in Study 2. Scores on ideology were calculated using the regression weights for the first component in Study 2. Because of a smaller sample size, a median split was used on this variable. Subjects

Table 8

Correlations of Political Ideology With Perceptions of the Allocation Task

\begin{tabular}{lc}
\hline \multicolumn{1}{c}{$\begin{array}{c}\text { Compared with other people } \\
\text { participating in this study, }\end{array}$} & $\begin{array}{c}\text { Political } \\
\text { conservatism }\end{array}$ \\
\hline $\begin{array}{l}\text { How harsh were your aid allocations? } \\
\text { How careful and mindful do you think you were in } \\
\text { making your decisions? }\end{array}$ & $.25^{* *}$ \\
$\begin{array}{l}\text { I would rather not make decisions regarding who } \\
\text { should receive versus be denied aid in these kinds } \\
\text { of programs. }\end{array}$ & $-.21^{* *}$ \\
$\begin{array}{l}\text { I feel awkward making these kinds of decisions. } \\
\text { Someone needs to decide these kinds of questions, and } \\
\text { I feel as qualified as the next person. }\end{array}$ & $-.17^{*}$ \\
\hline
\end{tabular}

${ }^{*} p<.05 . \quad{ }^{* *} p<.01$. 
scoring above the median on the first component were designated conservatives, whereas those scoring below the median were designated liberals.

\section{Results}

\section{Manipulation Checks}

Manipulation checks indicated that subjects believed that it is more likely that alcoholics can reform than people who suffer from a lack of motivation, $t(41)=2.15, p<.05$. In addition, subjects found it easier to believe that the alcoholic had solved his or her drinking problem than the loafer had solved his or her problem, $t(41)=2.03, p<.05$. These effects were not qualified by political orientation of the perceiver (i.e., political ideology did not interact with reformed drunk vs. reformed loafer), but liberals were more likely to believe that the claimants had reformed than were conservatives, $F(1,41)=7.39, p<.01$.

\section{Allocations of Vocational Training}

Only 7 of the 42 subjects ( $17 \%$ ) helped all of the claimants for assistance. Liberals were no more likely than conservatives to help everyone.

Analysis of the Political Ideology (2: Conservative, Liberal) $\times$ Locus of Responsibility (5: unreformed alcoholic, reformed alcoholic, unreformed loafer, reformed loafer, average of nonresponsible [IU, EC, and EU] claimants) ${ }^{9} \times$ Job Aptitude $(2) \times$ Market demand (2) mixed ANOVA revealed significant main effects for locus of responsibility, $F(4,156)=53.68, p<.01$ and market demand, $F(1,39)=7.30, p<.01$. Tukey post hoc tests indicated that the unreformed alcoholic and loafer were chosen least often to receive assistance $(M \mathrm{~s}=0.95$ and 1.32 out of a possible maximum of 4 ; no significant difference). Reformed loafers were chosen more often than the unreformed claimants $(M=2.32)$, but less often than reformed alcoholics $(M=3.54)$ or claimants with other causes of need (e.g., IU, EC, or EU causes; $M=3.79$ ). Reformed alcoholics were as likely to receive assistance as claimants with no personal responsibility for needing assistance. Claimants with high market demand (75\% odds of getting a job after training) were more likely to receive vocational training than those with moderate market demand $(50 \%$ odds of getting a job after training).

Two interaction effects reached significance: The Predicted Political Ideology $\times$ Locus of Responsibility Interaction, $F(4$, $156)=3.02, p<.05$, and the Locus of Responsibility $\times$ Market Demand $\times$ Job Aptitude interaction, $F(4,156)=4.27, p<.01$.

It will be recalled that subjects rated the alcoholic as more reformable than the loafer. This distinction colors the results that follow. The Political Ideology $\times$ Locus of Responsibility interaction supported the second-chance version of the deterrence hypothesis with the reformed alcoholic (see Table 9 for more detail), but the no-second-chance hypothesis with the reformed loafer. Analysis of the simple main effect of locus of responsibility for conservative subjects yielded a significant effect, $F(4,156)=177.24, p<.01$. Conservatives chose reformed alcoholics to receive vocational training as often as they chose claimants not responsible for needing assistance (IU, EC, and EU claimants), $F(1,156)=0.03$, ns. Reformed loafers were, however, chosen only half as often by conservatives as re-
Table 9

Average Number of Claimants Chosen as a Function

of Locus of Responsibility, Reform; and Political

Ideology of the Allocator

\begin{tabular}{lcc}
\hline \multicolumn{1}{c}{ Variable } & Liberals & Conservatives \\
\hline Loafer (internal-controllable) & 1.89 & 0.87 \\
Alcoholic (internal-controllable) & 1.39 & 0.61 \\
Reformed loafer & 2.83 & 1.91 \\
Reformed alcoholic & 3.33 & 3.70 \\
Other causes & 3.87 & 3.72 \\
\hline
\end{tabular}

formed alcoholics and nonresponsible claimants, $F(1,156)=$ $130.14, p<.01$. Unrepentant claimants were chosen less than all other claimants, with no differentiation between unrepentant alcoholics or unrepentant loafers.

In short, conservatives acted in accord with the deterrence hypothesis, but only if they believed reform had truly occurred. When conservatives believe claimants have changed their ways, reformed personally responsible claimants receive as much assistance as claimants who are not personally responsible for their predicament (at least under no scarcity).

A simple main effect for locus of responsibility also emerged among liberal allocators, $F(4,156)=64.51, p<.01$. Analysis indicated that all pair-wise comparisons between levels of locus of responsibility (and reform) were significant. Liberals allocated the most assistance to IU, EC, and EU claimants, followed by reformed alcoholics, reformed loafers, unrepentant loafers, and last, unrepentant alcoholics (see Table 9 for more detail). Liberals and conservatives were equally likely to assist claimants with IU, EC, or EU causes of need, but conservatives actually provided more assistance to reformed alcoholics than did liberals, $F(1,156)=3.84, p<.05$ (a reversal of the usual effects for political ideology). Liberals were significantly more likely to help unrepentant personally responsible claimants and reformed loafers than conservatives.

To distinguish further between the punitiveness and two deterrence hypotheses, we examined the mediational role of negative affect between attributions of responsibility and allocations. Psychometricians argue that a variable functions as a mediator when three conditions are met (see Baron \& Kenny, 1986; Judd \& Kenny, 1986): (a) variation in the independent variable accounts for significant variation in the dependent variable; (b) when controlling for the proposed mediator, the effects of the independent variables on the outcome variable are reduced to nonsignificance; and (c) variations in the proposed mediator accounts for significant variations in the dependent measure.

The previous analysis supports the first condition: Political ideology and locus of responsibility interacted to affect which claimants were chosen to receive assistance. To investigate whether controlling for positive and/or negative affect reduced

\footnotetext{
${ }^{9} \mathrm{IU}, \mathrm{EC}$, and EU claimants were not hypothesized to differ, and were collapsed into a single group for ease of interpretation. Post hoc analyses supported our expectation that there were no meaningful differences in reaction to claimants not responsible for their predicament.
} 
the political ideology by locus of responsibility interaction to nonsignificance, we tested the political ideology by locus of responsibility interaction controlling for positive and negative affect in separate ANCOVAs. Controlling for negative affective reactions to claimants reduced the ideology by locus of responsibility interaction to nonsignificance, $F(4,152)=1.48$, ns. Controlling for positive affective reactions to claimants did not change the interaction. Therefore the second condition for establishing that negative affect mediates the relationship between political ideology and attributional analysis and allocation decisions was satisfied.

To meet the third condition (that variation in the proposed mediator accounts for variation in the dependent measure), negative affective reactions toward claimants were correlated with the number of claimants assisted. As expected, increased negative affect toward claimants was associated with reduced assistance, $r(39)=-.43, p<.01$. Similarly, the partial correlation (controlling for political ideology, ratings of personal responsibility of claimants, and the interaction of the two) between negative affect and assistance was also robust, $r(32)=$ $-.30, p<.05$, satisfying the third criterion for mediation.

The role of negative affect as a mediator of the political ideology by locus of responsibility interaction effects on allocations supports the punitiveness interpretation of conservatives' policy preferences over the purely cognitive deterrence hypothesis.

\section{Discussion}

Do conservatives allocate public resources to personally responsible claimants who turn over a new leaf? OR do conservatives deny assistance even to penitent internal-controllable claimants in order to punish them for their carelessness and lack of foresight? The results reveal the limits of conservatives' punitiveness. In support of the second-chance version of the deterrence hypothesis, conservatives assisted personally responsible claimants as long as they were convinced that these claimants had reformed. When reform did not occur or was not convincing (subjects considered laziness less curable than alcoholism), the results were more consistent with the punitiveness hypothesis.

Interestingly, conservatives helped reformed alcoholics (the most credible manipulation of reform) even more than did liberals. This result parallels findings reported by Sniderman, Piazza, Tetlock, and Kendrick (1991), who found paradoxically that conservatives were more willing than liberals to provide government assistance to laid-off but dependable Black workers. Because conservatives tend to hold unflattering base-rate beliefs about African-Americans, they perceive a dependable Black to be an exception to the rule. The dependable Black worker stands out as an unusual example of individual effort and self-reliance conservatives so admire (a violation of expectancy; Jones \& McGillis, 1976).

Although the primary goal of Study 3 was to investigate competing psychological accounts of conservatives' allocation policies, the study also illustrated the limits of liberal egalitarianism. When confronted by an applicant pool that included both reformed and unreformed personally responsible claimants, liberals were less generous to the unreformed than they were when the pool included only the unreformed. Liberal egalitari- ans may assume few people abuse entitlement programs, that only the deserving ask for assistance, and that leakage from the transfer-payment bucket is minimal (Okun, 1975). Even the patience and generosity of liberals are tried, however, when confronted with blatant abusers of the system (unreformed personally responsible claimants) whose claims are pitted against those who have successfully reformed.

In summary, this study demonstrated that conservative punitiveness toward norm violators can be attenuated under some conditions. Specifically, when conservatives are convinced that personally responsible claimants have reformed, they give second chances and provide assistance. When liberals are faced with a claimant population that includes both reformed and unrepentant claimants, they are less inclined to help the unreformed than when the issue of reform has not been made salient.

\section{Conclusion}

This article has explored competing cognitive and motivational explanations for liberal and conservative approaches to allocating public assistance. Taken together, the results paint a coherent picture of conservative and liberal judgment policies in a variety of settings. Allocations by conservatives under no scarcity are remarkably consistent across situations. Conservatives typically deny help to claimants who are personally responsible for their predicament, and they do so even in life-anddeath settings. Claimants who need help for other reasons receive some help from conservatives, but less than they would have from liberals. In the situations studied-monetary allocations to health-care programs, allocations of AZT to AIDS patients, vocational training to the unemployed, and postwar foreign aid (see also Skitka et al., 1991, Skitka \& Tetlock, 1992)_the results repeatedly point to punitiveness as a key motive that drives allocations by conservatives, a motive that is difficult to reduce to concern for promoting efficiency by creating incentives for good conduct. Although the libertarian image of conservatism would predict conservative reluctance to expand social programs is motivated solely by a commitment to economic freedom (minimize taxes) and self-reliance (minimize dępendency on government), the data suggest that negative affective reactions toward norm violators play a more important role in driving conservative opposition than do ideological arguments organized around the values of either self-reliance or efficiency.

However, this research also points to the limits of conservative hostility toward people personally responsible for their predicament. If people reform their behavior and live up to societal norms, most conservatives do not hold a grudge and continue to withhold assistance. If conservatives find the personal transformation credible, they allow for second chances and provide assistance.

Allocations by liberals are more variable and contextually dependent than those by conservatives. On the one hand, under scarcity, liberals act like conservatives and withhold assistance from personally responsible claimants (Skitka \& Tetlock, 1992). The current studies also demonstrated that under no scarcity liberals allocated resources more like conservatives when the allocation setting stressed the free-market goal of efficiency (e.g., vocational training for the unemployed) as opposed to the 
humanitarian goal of reducing suffering (health-care allocations). On the other hand, liberals helped all AZT claimants in the present studies, a result consistent with Skitka and Tetlock's (1992) findings in the AZT, organ transplantation, and low-income housing domains.

One theoretical approach is to argue, in the spirit of signal detection theory, that these findings reflect differences in the perceived costs or likelihoods of making Type I versus Type II errors across policy domains. If a deserving person does not get AZT treatment (a Type I error), the cost of this error is certain death. But if a deserving person does not get vocational training, the cost is not so high; he or she loses only a job opportunity. One possibility is that liberals accept a higher Type II error rate in the AIDS domain (accept that some undeserving people will receive assistance) to minimize Type I errors (the danger of denying the deserving). Another possibility is that liberals believe that no one-no matter how recklessly they behaved-deserves to be denied access to medical treatment for life-threatening diseases, and that is impossible in such cases to make Type II errors. Whichever interpretation is correct, this signal detection analysis suggests that liberals will make the AZT decisions much more quickly and confidently than the vocational training decisions, and will overwhelmingly favor helping everyone in the AZT domain but will be more cautious and discriminating (prone to accept Type I vs. Type II trade-offs) in the vocational training domain. In short, trade-off avoidance among liberals will be most pronounced when the trade-off requires comparisons that feel morally illegitimate (lives vs. money as opposed to jobs vs. money; jobs are widely regarded as fungible, whereas lives are not).

Another theoretical approach is to argue, in the spirit of Maslow's need hierarchy (Inglehart, 1977), that egalitarian values may be primed most powerfully in resource domains critical for physical survival, such as food, health, and shelter. Although job training augments the likelihood that claimants can satisfy their primary needs, it may be perceived as a relative luxury given the number of job openings at the low end of the income distribution. Dignity, status, and upward mobility may be perceived as extras, not to be doled out even by liberals to people who have brought ill-fortune upon themselves. But when resources are linked directly to survival, such as medical treatment, liberals expand the boundaries of the moral community to include even those who have recklessly placed themselves in peril.

In closing, we caution against allowing our own political preconceptions to color our psychological portraits of liberal and conservative policies (see also Tetlock \& Mitchell, 1993). Political partisans may be tempted to use particular findings to praise themselves or to stigmatize opponents. Depending on one's partisan preferences, one can put very different value spins on the data reported here. One might, for example, praise or criticize conservatives for allocating resources to reward self-reliance and punish irresponsibility and laziness. Conservatives set up these reward contingencies in a "principled" or "rigid" fashion, regardless of resource scarcity or abundance and type of resource to be distributed. This is not to say conservatives dispassionately enforce societal norms, but their anger toward norm violators can be characterized in a sympathetic light (controlled indignation that recedes when free-riders mend their ways) or in an unsympathetic light (overly self-righteous, unempathic, and homophobic). In a similar vein, the willingness of liberals to help everyone whenever possible might be praised as generous and open-minded or criticized as being oblivious to opportunity costs (could the money be better spent in other ways, e.g., research, or even rebated back to tax payers?). The tendency of liberals to avoid trade-offs that pit lives against money may be cast in terms of the higher levels of Kolhbergian moral development among liberals or in terms of the greater unwillingness of liberals to confront the tragic choices that life eventually thrusts upon us.

Vexing normative issues to the side, our results extend psychological theorizing on ideology (both liberal egalitarianism and right-wing-authoritarianism), as well as distributive and retributive justice. We now know more than we did before about who is willing to extend public aid to whom, when they are willing or unwilling to do so, and (to some degree) why they are willing or unwilling to do so.

\section{References}

Abelson, R. P. (1981). Psychological status of the script concept. American Psychologist, 36, 715-729.

Abelson, R. P., \& Levi, A. (1985). Decision making and decision theory. In E. Aronson \& G. Lindzey (Eds.), Handbook of social psychology (3rd ed., pp. 231-310). Reading, MA: Addison-Wesley.

Adorno, T. W., Frenkel-Brunswik, E., Levinson, D. J., \& Sanford, R. N. (1950). The authoritarian personality. New York: Harper.

Alker, H. A., \& Poppen, P. J. (1973). Personality and ideology in university students. Journal of Personality, 41, 652-671.

Altemeyer, B. (1981). Right-wing authoritarianism. Winnipeg: University of Manitoba Press.

Altemeyer, B. (1988). Enemies of freedom: Understanding right-wing authoritarianism. San Francisco: Jossey-Bass.

Baron, J. ( 1993). Heuristics and biases in equity judgments: A utilitarian approach. In B. Mellers \& J. Baron (Eds.), Psychological perspectives in justice (pp. 109-137). Cambridge, England: Cambridge University Press.

Baron, R. M., \& Kenny, D. A. (1986). The moderator-mediator variable distinction in social psychological research: Conceptual, strategic, and statistical considerations. Journal of Personality and Social Psychology, 51, 1173-1182.

Betancourt, H. (1990). An attribution-empathy model of helping behavior: Behavioral intentions and judgments of help-giving. Personality and Social Psychology Bulletin, 16, 573-591.

Betancourt, H., \& Blair, I. (1992). A cognition (attribution)-emotion model of violence in conflict situations. Personality and Social Psychology Bulletin, 18, 343-350.

Bobo, L. (1983). White opposition to busing: Symbolic racism or realistic group conflict? Journal of Personality and Social Psychology, 45, 1196-1210.

Carroll, J., Perkowitz, W., Lurigio, A., \& Weaver, K. (1987). Sentencing goals, causal attributions, and personality. Journal of Personality and Social Psychology, 52, 107-118.

Chapman, D. P., Levin, I. P., \& Kuhn, K. M. (1991). Information integration in AIDS treatment decisions. Paper presented at the Midwestern Psychological Association, Chicago, IL.

Cherry, F., \& Byrne, D. (1977). Authoritarianism. In T. Blass (Ed.), Personality variables in social behavior (pp. 109-133). Hillsdale, NJ: Lawrence Erlbaum,

Eysenck, H. J. (1971). Social attitudes and social class. British Journal of Social and Clinical Psychology, 10, 201-212.

Feather, N. (1985). Attitudes, values, and attributions: Explanations of 
unemployment. Journal of Personality and Social Psychology, 48, 876-889.

Garrett, J. B. (1973, August). Effects of Protestant ethic endorsement on equity behavior. In L. Messé (Chair), Individual differences in equity behavior. Symposium conducted at the 81 th Annual Convention of the American Psychological Association, Montreal, Canada.

Gilder, G. (1981). Wealth and poverty. New York: Basic Books.

Greenberg, J. (1978). Equity, equality, and the Protestant ethic: Allocating rewards following fair and unfair competition. Journal of Experimental and Social Psychology, 14, 217-226.

Greenwald, A. (1975). Consequences of prejudice against the null hypothesis. Psychological Bulletin, 82, 1-20.

Hatziandreu, E., Graham, D. D., \& Soto, M. A. (1988). AIDS and biomedical research funding: Comparative analysis. Review of Infectious Diseases, 10, 159-167.

Herek, G. M. (1987). Can functions be measured? A new perspective on the functional approach to attitudes. Social Psychology Quarterly, 50, 285-303.

Herek, G. M. (1989). Hate crimes against lesbians and gay men: Issues for research and policy. American Psychologist, 44, 948-955.

Herek, G. M., \& Glunt, E. K. (1988). An epidemic of stigma: Public reactions to AIDS. American Psychologist, 43, 886-891.

Hogan, R., \& Dickstein, E. (1972). Moral judgments and perceptions of injustice. Journal of Personality and Social Psychology, 23, 409-413.

Inglehart, R. (1977). The silent revolution. Princeton, NJ: Princeton University Press.

Janis, I. L., \& Mann, L. (1977). Decision making: A psychological analysis of conflict, choice, and commitment. New York: Free Press.

Jencks, C. (1992). Rethinking social policy: Race, poverty, and the underclass. Cambridge, MA: Harvard University Press.

Jones, E. E., \& McGillis, D. (1976). Correspondent inferences and the attribution cube: A comparative reappraisal. In J. H. Harvey, W. J. Ickes, \& R. F. Kidd (Eds.), New directions in attribution research (Vol. 1, pp. 389-420). Hillsdale, NJ: Erlbaum.

Judd, C. M., \& Kenny, D. A. (1986). Estimating the effects of social interventions. Cambridge, England: Cambridge University Press.

Katz, I., \& Hass, R. G. (1988). Racial ambivalence and American value conflict: Correlational and priming studies of dual cognitive structures. Journal of Personality and Social Psychology, 55, 893-905.

Kite, M. E., Whitley, Jr., B. E., Michael, S. T., \& Simon, T. L. (1991). Response to AIDS patients: The roles of source of infection and victim sexual orientation. Paper presented at the Midwestern Psychological Association, Chicago, IL.

Kluegel, J. R. (1990). Trends in Whites' explanations of the BlackWhite gap in socioeconomic status, 1977-1989. American Sociological Review, 55, 512-525.

Kluegel, J. R., \& Smith, E. R. (1986). Beliefs about inequality. New York: Aldine.

Krieger, N. (1988). AIDS funding: Competing needs and the politics of priorities. International Journal of Health Services, 18, 521-541.

Langer, E. J. (1978). Rethinking the role of thought in social interaction. In J. Harvey, W. Ickes, \& R. F. Kidd (Eds.), New directions in attribution research (Vol. 2). Hillsdale, NJ: Erlbaum.

Levin, I. P., \& Chapman, D. P. (1990). Risk taking, frame of reference, and characterization of victim groups in AIDS treatment decisions. Journal of Experimental Social Psychology, 26, 421-434.

Levitan, S., \& Johnson, C. M. (1984). Beyond the safety net: Reviving the promise of opportunity in America. Cambridge, MA: Ballinger.

MacDonald, A. P., Jr. (1971). Correlates of the ethics of personal conscience and the ethics of social responsibility. Journal of Consulting and Clinical Psychology, 37, 443.

Major, B., \& Deaux, K. (1982). Individual differences in justice behavior. In J. Greenberg \& R. L. Cohen (Eds.), Equity and justice in social behavior. San Diego, CA: Academic Press.
Mallery, P. (1990). Attributions and attitudes toward AIDS. Unpublished manuscript, University of California, Los Angeles.

Murray, C. (1984). Losing ground: American social policy, 1950-1980. New York: Basic Books.

Okun, A. M. (1975). Equality and efficiency: The big tradeoff. Washington, D.C., The Brookings Institution.

Ostrow, D. G., \& Traugott, M. (1988). Public policy for AIDS: Determinants of public preferences. Paper presented at the Kinsey Institute Symposium on AIDS and the Media, Bloomington, IN.

Peterson, B. E., Doty, R. M., \& Winter, D. G. (1993). Authoritarianism and attitudes toward contemporary social issues. Personality and $S_{O}$ cial Psychology Bulletin, 19, 174-184.

Price, V., \& Hsu, M. (1992). Public opinion about AIDS policies: The role of misinformation and attitudes toward homosexuals. Public Opinion Quarterly, 56, 29-52.

Rasinski, K. A. (1987). What's fair is fair: Or is it? Journal of Personality and Social Psychology, 53, 201-211.

Rogers, D. E. (1989). Federal spending on AIDS-how much is enough? The New England Journal of Medicine, 320, 1623-1624.

Russell, D., McAuley, E., \& Tarico, V. (1987). Measuring causal attributions for success and failure: A comparison of methodologies for assessing causal dimensions. Journal of Personality and Social Psychology, 52, 1248-1257.

Schlesinger, A. (1986). The cycles of American history. Boston: Houghton-Mifflin.

Schwartz, J. E. (1983). American's hidden success: A reassessment of twenty years of public policy. New York: Norton.

Schwarzer, R., \& Weiner, B. (1991). Stigma controllability and coping as predictors of emotions and social support. Journal of Social and Personality Relationships, 8, 133-140.

Skitka, L. J., McMurray, P. J., \& Burroughs, T. E. (1991). Willingness to provide post-war aid to Iraq and Kuwait: An application of the contingency model of distributive justice. Contemporary Social Psychology, 15, 179-188.

Skitka, L. J., \& Tetlock, P. E. (1992). Allocating scarce resources: A contingency model of distributive justice. Journal of Experimental Social Psychology, 28, 33-37.

Skitka, L. J., \& Tetlock, P. E. (1993). Of ants and grasshoppers: The political psychology of allocating public assistance. In B. Mellers \& J. Baron (Eds.), Psychological perspectives in justice (pp. 205-233). New York: Cambridge University Press.

Sniderman, P., Hagen, M. G., Tetlock, P. E., \& Brady, H. E. (1986). Reasoning chains: Causal models of policy reasoning in mass publics. British Journal of Political Science, 16, 405-430.

Sniderman, P. M., Piazza, T., Tetlock, P. E., \& Kendrick, A. (1991). The new racism. American Journal of Political Science, 35, 423-447.

Sniderman, P., \& Tetlock, P. E. (1986). The interrelationships between political ideology and public opinion. In M. Herman (Ed.), Handbook of political psychology. San Francisco: Jossey-Bass.

Sniderman, P., Wolfinger, B., Mutz, D., \& Wiley, J. (1987). Values under pressure: $A I D S$ and civil liberties. Paper presented at the annual conference of the American Political Science Association, Chicago, IL.

Tetlock, P. E. (1984). Cognitive style and political belief systems in the British House of Commons. Journal of Personality and Social PSychology, 46, 365-375.

Tetlock, P. E. (1986). A value pluralism model of ideological reasoning. Journal of Personality and Social Psychology, 50, 819-827.

Tetlock, P. E., \& Boettger, R. (1992). Accountability amplifies the status quo effect when change creates victims. Unpublished manuscript, University of California, Berkeley.

Tetlock, P. E., \& Mitchell, P. G. (1993). Liberal and conservative approaches to justice: Conflicting psychopolitical portraits. In B. Mellers \& J. Baron (Eds.), Psychological perspectives on justice (pp. 234258). Cambridge, England: Cambridge University Press. 
Tomkins, S. S. (1965). Affect and the psychology of knowledge. In S. S. Tomkins \& C. E. Izard (Eds.), Affect, cognition, and personality. New York: Springer.

Triplet, R. G., \& Sugarman, D. B. (1987). Reactions to AIDS victims: Ambiguity breeds contempt. Personality and Social Psychology Bulletin, 13, 265-274.

Weiner, B. (1986). An attributional theory of motivation and emotion. New York: Springer-Verlag.

Weiner, B. (1992). AIDS from an attributional perspective. In J, B. Pryor \& G. D. Reeder (Eds.), The social psychology of HIV infection. Hillsdale, NJ: Erlbaum.

Weiner, B., Perry, R. B., \& Magnusson, J. (1988). An attributional analysis of reactions to stigmas. Journal of Personality and Social Psychology, 55, 738-748.
Williams, S. (1984). Left-right ideological differences in blaming victims. Political Psychology, 5, 573-581.

Winkenwerder, W., Kessler, A. R., \& Stolec, R. M. (1989). Federal spending for illness caused by the human immunodeficiency virus. The New England Journal of Medicine, 320, 1598-1603.

Winter, D. G. (1990). Authoritarianism at 40 [Review of Enemies of freedom: Understanding right-wing authoritarianism]. Contemporary Psychology, 35, 460-461.

Wong, P. T. P., \& Weiner, B. (1981). When people ask "why" questions, and the heuristics of attributional search. Journal of Personality and Social Psychology, 40, 650-663.

Received July 20, 1992

Revision received May 6, 1993

Accepted May 24, 1993

\section{American Psychological Association} SUBSCRIPTION CLAIMS INFORMATION

Today's Date:

We provide this form to assist members, institutions, and nonmember individuals with any subscription problems. With the appropriate information we can begin a resolution. If you use the services of an agent, please do NOT duplicate claims through them and directly to us. PLEASE PRINT CLEARLY AND IN INK IF POSSIBLE.

\begin{tabular}{l}
\hline PRINT FUL $I$ NAME OR KEY NAME OF NSTTTUTION \\
\hline ADDRESS \\
\hline CITY
\end{tabular}

YOUR NAME AND PHONE NUMBER

TTTLE

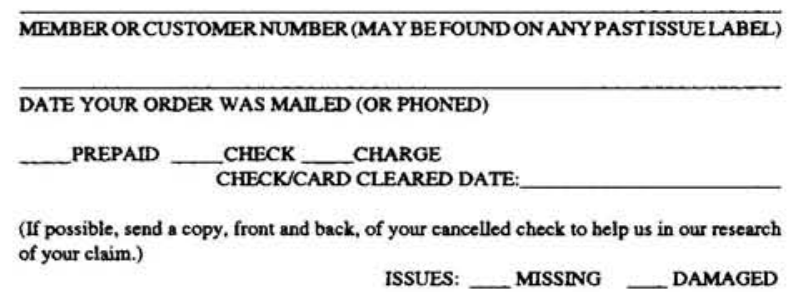

VOLUME OR YEAR

Thank you. Once a claim is received and resolved, delivery of replacement issues routinely takes 4-6 weeks.

(TO BE FILLED OUT BY APA STAFF)

DATE RECEIVED:

ACTION TAKEN:

STAFF NAME:
DATE OF ACTION:

INV. NO. \& DATE:

LABEL NO. \& DATE,

Send this form to APA Subscription Claims, 750 First Street, NE, Washington, DC 20002-4242

PLEASE DO NOT REMOVE. A PHOTOCOPY MAY BE USED. 